\title{
Contrasting trait syndromes in angiosperms and conifers are associated with different responses of tree growth to temperature on a large scale
}

\author{
Jofre Carnicer ${ }^{1,2,3 *}$, Adrià Barbeta ${ }^{2,3}$, Dominik Sperlich ${ }^{2,3,4}$, Marta Coll ${ }^{2,3}$ and Josep Peñuelas ${ }^{2,3}$ \\ ${ }^{1}$ Community and Conservation Ecology Group, Centre for Ecological and Evolutionary Studies, University of Groningen, Groningen, Netherlands \\ ${ }^{2}$ CREAF, Barcelona, Spain \\ ${ }^{3}$ Global Ecology Unit, Consejo Superior de Investigaciones Cientificas, CREAF-CEAB-CSIC-UAB, Barcelona, Spain \\ ${ }^{4}$ Department of Ecology, University of Barcelona, Barcelona, Spain
}

\section{Edited by:}

Nate McDowell, Los Alamos

National Laboratory, USA

\section{Reviewed by:}

Frank Gallagher, Rutgers the State

University of New Jersey, USA

Henrik Hartmann, Max-Planck

Institute for Biogeochemistry,

Germany

\section{*Correspondence:}

Jofre Carnicer, Community and Conservation Ecology Group, Centre

for Ecological and Evolutionary

Studies, University of Groningen,

Nijenborgh 7, 9747 AG Groningen,

Netherlands

e-mail: jofrecarnicer@yahoo.es
Recent large-scale studies of tree growth in the Iberian Peninsula reported contrasting positive and negative effects of temperature in Mediterranean angiosperms and conifers. Here we review the different hypotheses that may explain these trends and propose that the observed contrasting responses of tree growth to temperature in this region could be associated with a continuum of trait differences between angiosperms and conifers. Angiosperm and conifer trees differ in the effects of phenology in their productivity, in their growth allometry, and in their sensitivity to competition. Moreover, angiosperms and conifers significantly differ in hydraulic safety margins, sensitivity of stomatal conductance to vapor-pressure deficit (VPD), xylem recovery capacity or the rate of carbon transfer. These differences could be explained by key features of the xylem such as non-structural carbohydrate content (NSC), wood parenchymal fraction or wood capacitance. We suggest that the reviewed trait differences define two contrasting ecophysiological strategies that may determine qualitatively different growth responses to increased temperature and drought. Improved reciprocal common garden experiments along altitudinal or latitudinal gradients would be key to quantify the relative importance of the different hypotheses reviewed. Finally, we show that warming impacts in this area occur in an ecological context characterized by the advance of forest succession and increased dominance of angiosperm trees over extensive areas. In this context, we examined the empirical relationships between the responses of tree growth to temperature and hydraulic safety margins in angiosperm and coniferous trees. Our findings suggest a future scenario in Mediterranean forests characterized by contrasting demographic responses in conifer and angiosperm trees to both temperature and forest succession, with increased dominance of angiosperm trees, and particularly negative impacts in pines.

Keywords: conifers, angiosperms, functional traits, mediterranean ecosystems, drought, temperature, carbon metabolism, growth

\section{INTRODUCTION}

The assimilation and allocation of carbon are fundamental processes allowing tree growth, development, survival, reproduction and defense (McDowell, 2011; Galiano et al., 2012; Sala et al., 2012). In addition, non-structural carbohydrates (NSCs) play a variety of functions in tree physiology, providing a temporal buffer to reconcile differences in carbon supply and demand, maintaining hydraulic transport and facilitating osmotic regulation, allowing leaf emergence and bud burst and actively participating in the prevention of frost and drought embolism and repair (Sala et al., 2012). The demographic performance of trees, however, is generally co-limited by other factors that frequently interact in complex ways with the processes of carbon uptake and allocation, such as direct climatic effects on photosynthesis, growth and nutrient uptake (Körner, 1998, 2003; Rennenberg et al., 2006), species-specific traits (Wright et al., 2004; Chave et al., 2009; Carnicer et al., 2012) or the impacts of secondary consumers and diseases (Bale et al., 2002).

Recent ecophysiological studies highlight the coupled dynamic links between NSC content in woody tissues and several climatedependent tree responses such as embolism prevention and repair, growth, bud burst and leaf emergence (Johnson et al., 2012; Sala et al., 2012; Meinzer and McCulloh, 2013). These studies suggest the existence of contrasting trait-based ecophysiological strategies in major plant groups (Choat et al., 2012; Johnson et al., 2012; Meinzer et al., 2013) such as angiosperm and coniferous trees. Arguably, a next necessary step is to analyze how these contrasting ecophysiological strategies may be influencing the distribution and abundance of tree species and their responses to global warming.

Recent large-scale studies have reported contrasting responses of growth to temperature in angiosperm and coniferous trees in 
Mediterranean forests of the Iberian Peninsula (Gómez-Aparicio et al., 2011; Coll et al., 2013). For example, Gómez-Aparicio et al. (2011) reported a positive effect of rising temperatures on growth of angiosperm trees, but neutral or negative effects on coniferous trees. These contrasting trends between the two phylogenetic groups were later also observed and confirmed by Coll et al. (2013). Critically, whereas a reduction in precipitation was predicted to decrease tree growth in both groups, increases in temperature could produce a performance disadvantage in conifers compared to angiosperm broadleaved trees (Gómez-Aparicio et al., 2011; Coll et al., 2013). Consistent with these empirical findings that associate the negative effects of temperatures and growth in Pinus species, palaeoecological studies suggest a persistent link between Pinaceae distributions and low temperatures during the last 100 million years (Millar, 1993; Brodribb et al., 2012). Cold periods in the Paleocene and Eocene are associated with an increased abundance of fossils of the genus Pinus, and the reverse occurs during warm periods (Millar, 1993; Brodribb et al., 2012). Similarly, warm periods during the Miocene and Pliocene are apparently associated with northward contractions of the ranges of Pinaceae species (Millar, 1993; Brodribb et al., 2012). Notably, the ecophysiological basis of these contrasting growth and distributional responses to temperature remain poorly discussed and resolved.

Here we review the hypotheses that may contribute to explain the observed contrasting responses of growth to temperature observed in Mediterranean conifers and angiosperms. We review the differences between Mediterranean conifer and angiosperm trees in growth-related traits, including phenology, crown allometry, sensitivity to competition, and drought and winter freezing responses. Furthermore, we hypothesize that angiosperm and coniferous ecophysiological strategies differentially integrate diverse traits such as stomatal sensitivity to vapor-pressure deficit (VPD), hydraulic safety margins and capacity for embolism repair, which in turn are linked to features of the xylem such as NSC content, carbon transfer rates, wood parenchymal fraction and wood capacitance. In sum, our main aims in this study are: (i) to list the different hypotheses that may explain contrasting growth responses to temperature in Mediterranean conifer and angiosperm trees and review the differences in ecophysiological traits associated with temperature- and droughtinduced responses in these two groups, (ii) to briefly review the multiple effects of temperature on basic tree ecophysiological functions (e.g., photosynthesis, growth, respiration and nutrient uptake and transport), (iii) to analyze the specific case study of forests in the Iberian Peninsula, which present diverging tree growth responses to temperature in Angiosperms and Conifers, and (iv) to briefly discuss the implications of our findings. Below we dedicate a section to each of these objectives.

\section{A REVIEW OF THE DIVERSE HYPOTHESES THAT MAY EXPLAIN CONTRASTING GROWTH RESPONSES TO TEMPERATURE IN MEDITERRANEAN AND ANGIOSPERM TREES}

Table 1 lists the different hypotheses that may explain contrasting growth trends to temperature in Mediterranean conifer and angiosperm trees. The first hypothesis (Table 1.1) states that positive growth responses to increased temperature in angiosperms could be mediated by a less strict stomatal control, allowing them to assimilate carbon for longer during warmer and drier periods. While this could imply that angiosperm could be more vulnerable to xylem cavitation and hydraulic failure, they have a greater capacity for embolism repair. On the other hand, most conifers function with a wider hydraulic safety margin to avoid cavitation but with the cost of lower carbon gain. Beside this specific hypothesis, several other factors could also contribute to explain the differences in growth responses between conifer and angiosperm trees. For example, these two groups differ in the effects of phenology in their productivity, in the sensitivity of growth to competition, and in growth allometry (Table 1.2-1.4). In addition, local adaptation processes and phenotypic plasticity also largely influence tree growth responses to temperature and drought (Table 1.5-1.9). Finally, the available empirical evidence suggests that the diverse factors significantly interact in determining growth responses (Table 1.7). For example, several studies report strong interactions between tree size, drought, and stand density effects in determining large-scale growth patterns in the Mediterranean basin. Below we briefly review the hypotheses listed in Table 1 and discuss the experimental tests required to assess their relative importance.

\section{ECO-PHYSIOLOGICAL AND HYDRAULIC TRAITS. DIFFERENT ECOPHYSIOLOGICAL AND CARBON-ALLOCATION STRATEGIES IN ANGIOSPERMS AND CONIFERS (HYPOTHESIS 1.1)}

Table 2 summarizes the trait differences between angiosperm and coniferous trees. Key traits that differ between these two groups include stomatal sensitivity to VPD, xylem anatomy, foliar traits, hydraulic safety margins, capacity for embolism repair, NSC content, carbon transfer rates, wood parenchymal fraction, and wood capacitance. The available published evidence shows that these diverse traits are functionally related and define two contrasting ecophysiological strategies in conifers and angiosperms. Compared to angiosperms, conifers have a lower stomatalconductance sensitivity to increased VPD (sensu Johnson et al., 2012). In turn, this key difference in stomatal response appears to be tightly related to the different hydraulic safety margins in both groups (Tyree and Sperry, 1988; Nardini et al., 2001; Table 2). The wider hydraulic safety margins in conifers thus imply early responses of stomatal closure, which reduce hydraulic conductivity before substantial cavitation occurs. On the other hand, angiosperms can maintain relatively high stomatal conductances even when the xylem pressure caused by high VPD is sufficient to induce extensive cavitation (Meinzer et al., 2009, 2013; Johnson et al., 2012).

In support of these trends, Choat et al. (2012) recently reported that species in coniferous forests generally have a higher resistance to drought-induced cavitation and operate with wider hydraulic safety margins than do angiosperms. The minimum xylem pressures in conifers measured in the field were more positive than the xylem pressures causing a $50 \%$ loss of hydraulic conductivity, and thus the risk of hydraulic failure by collapse of the water-conducting system was low. In contrast, the hydraulic 


\section{Table 1 | Main hypotheses that may contribute to explain contrasting growth responses to temperature in Iberian Angiosperm and Conifer} trees on a large scale.

\begin{tabular}{|c|c|c|c|}
\hline Hypotheses & Angiosperms & Conifers & References \\
\hline $\begin{array}{l}1.1 \text { Eco-physiological and } \\
\text { hydraulic traits }\end{array}$ & $\begin{array}{l}\text { Narrower hydraulic safety } \\
\text { margins and higher capacity } \\
\text { to reverse embolisms }\end{array}$ & $\begin{array}{l}\text { Wide hydraulic safety margins, } \\
\text { early drought-induced stomatal } \\
\text { closure and lower carbon gain, } \\
\text { low stomatal conductance } \\
\text { sensitivity to VPD }\end{array}$ & $\begin{array}{l}\text { Martínez-Ferri et al., 2000; Brodersen } \\
\text { et al., 2010; Choat et al., 2012; Epron et al., } \\
\text { 2012; Johnson et al., 2012; Michelot et al., } \\
\text { 2012; Sala et al., 2012; Brodersen and } \\
\text { McElrone, 2013; Coll et al., 2013; Meinzer } \\
\text { et al., 2013; Ogasa et al., } 2013\end{array}$ \\
\hline
\end{tabular}

\begin{tabular}{|c|c|c|c|}
\hline 1.2 Phenology & $\begin{array}{l}\text { Tree productivity more } \\
\text { sensitive to growing season } \\
\text { length }\end{array}$ & $\begin{array}{l}\text { Positively affected but less } \\
\text { sensitive to growing season } \\
\text { length }\end{array}$ & $\begin{array}{l}\text { Churkina et al., 2005; Piao et al., 2007; } \\
\text { Welp et al., 2007; Delpierre et al., 2009; } \\
\text { Richardson et al., 2010; Gómez-Aparicio } \\
\text { et al., 2011; Coll et al., } 2013\end{array}$ \\
\hline $\begin{array}{l}1.3 \text { Intra- and inter-specific } \\
\text { competition and forest } \\
\text { succession }\end{array}$ & $\begin{array}{l}\text { Growth less sensitive to intra } \\
\text { and inter-specific stand } \\
\text { competition }\end{array}$ & $\begin{array}{l}\text { Growth severely reduced by intra- } \\
\text { and inter-specific competence in } \\
\text { small, non-dominant trees }\end{array}$ & $\begin{array}{l}\text { Sánchez-Gómez et al., 2008; } \\
\text { Gómez-Aparicio et al., 2011; Carnicer et al., } \\
\text { 2013a; Coll et al., 2013; Vayreda et al., } 2013\end{array}$ \\
\hline 1.4 Size, age and allometry & $\begin{array}{l}\text { Different growth allometry } \\
\text { and less apical dominance }\end{array}$ & $\begin{array}{l}\text { Peak of crown growth reached at } \\
\text { lower sizes }\end{array}$ & $\begin{array}{l}\text { Gómez-Aparicio et al., 2011; Poorter et al., } \\
2012\end{array}$ \\
\hline 1.5 Drought and temperature & $\begin{array}{l}\text { Angiosperm trees are able to } \\
\text { maintain substantial } \\
\text { transpiration levels during } \\
\text { summer drought events }\end{array}$ & $\begin{array}{l}\text { Drought and heat waves often } \\
\text { results in early stomatal closure in } \\
\text { Mediterranean conifers }\end{array}$ & $\begin{array}{l}\text { Martínez-Ferri et al., 2000; de Luis et al., } \\
\text { 2007, 2011; Zweifel et al., 2007; Eilmann } \\
\text { et al., 2009; Camarero et al., 2010; Klein } \\
\text { et al., 2011; Coll et al., 2013; Poyatos et al., } \\
2013\end{array}$ \\
\hline
\end{tabular}

\begin{tabular}{|c|c|c|c|}
\hline 1.6 Winter freezing & $\begin{array}{l}\text { Angiosperm trees are more } \\
\text { vulnerable to freeze-thaw } \\
\text { embolism }\end{array}$ & $\begin{array}{l}\text { Less sensitive to freeze-thaw } \\
\text { embolism }\end{array}$ & $\begin{array}{l}\text { Sperry and Sullivan, 1992; Gómez-Aparicio } \\
\text { et al., 2011; Brodribb et al., } 2012\end{array}$ \\
\hline $\begin{array}{l}1.7 \text { Interactions between multiple } \\
\text { factors }\end{array}$ & Yes & Yes & $\begin{array}{l}\text { Linares et al., 2010; Gómez-Aparicio et al., } \\
\text { 2011; Vayreda et al., 2012; Coll et al., 2013; } \\
\text { Ruiz-Benito et al., } 2013\end{array}$ \\
\hline $\begin{array}{l}\text { 1.8 Local adaptation, individual } \\
\text { and provenance variation }\end{array}$ & Yes & Yes & $\begin{array}{l}\text { Rehfeldt, 1978, 1982; Santos et al., 2010; } \\
\text { Ramírez-Valiente et al., 2010, 2011; } \\
\text { Chmura et al., 2011; Robson et al., 2012; } \\
\text { Alberto et al., } 2013\end{array}$ \\
\hline 1.9 Phenotypic plasticity & Yes & Yes & $\begin{array}{l}\text { Camarero et al., 2010; Nicotra et al., 2010; } \\
\text { de Luis et al., } 2011\end{array}$ \\
\hline
\end{tabular}

safety margins reported for angiosperms were narrower, being slightly positive or even negative.

The reported differences in stomatal sensitivity and hydraulic safety margins have in turn been functionally associated with different responses between both groups in the capacity of xylems to recover from embolisms. Recent studies have reported higher capacities in species with narrow safety margins and higher stomatal sensitivities to VPD (see Johnson et al., 2012 for a precise definition of stomatal sensitivity to VPD; Meinzer et al., 2013). The reversal of cavitation has been demonstrated to be feasible on an hourly or daily basis and to occur even under high xylem tension (Hacke and Sperry, 2003; Salleo et al., 2004; Brodersen et al., 2010; Zufferey et al., 2011). Two general but contrasting hydraulic strategies arise: (i) high cavitation resistance, low stomatal sensitivity to VPD and low resilience (gymnosperms) and (ii) low cavitation resistance but high resilience (angiosperms).

These two basic strategies are in turn functionally linked to anatomical differences in cell anatomy, NSC content, wood parenchymal fraction, and wood density (Table 2). For example, both the percentage of living parenchyma and the concentration of NSCs in the xylem are significantly higher in angiosperms than in conifers (Johnson et al., 2012 and citations therein). During the reversal of embolisms, vessel refilling probably requires an input of energy (Meinzer et al., 2013) and the mobilization of stored carbohydrates. Living wood parenchyma thus acts as a reservoir of both water and carbohydrates. Hence, NSCs stored in cells surrounding vessels are likely to be the source of sugars needed for the maintenance of vascular integrity (Brodersen et al., 2010; 
Table 2 | Summary of differences in key functional traits between conifers and angiosperms.

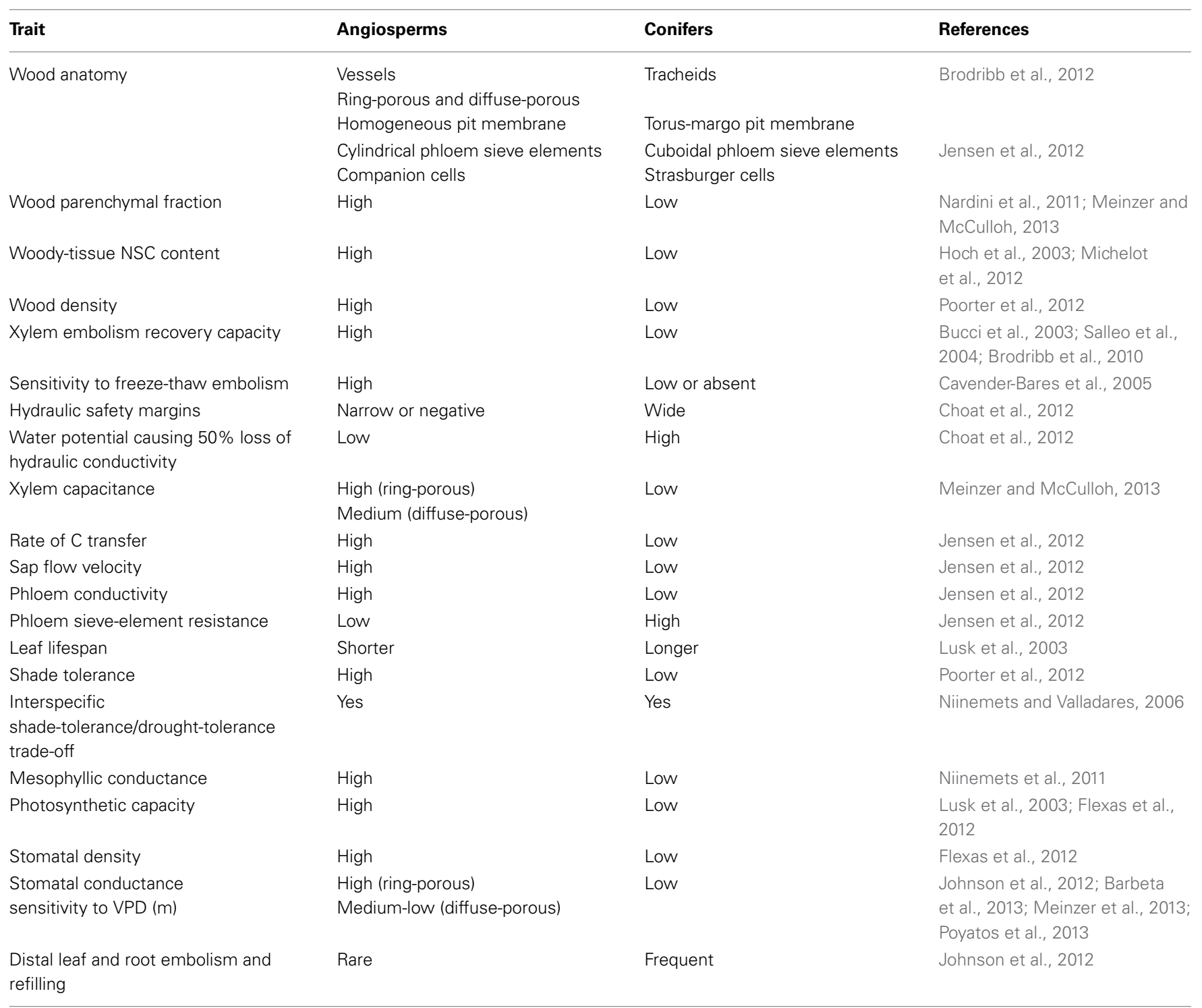

Sala et al., 2012). Sugars are possibly transferred from parenchymal cells to embolized vessels for establishing a gradient to drive water away from either the phloem (Nardini et al., 2011) or nonembolized vessels (Brodersen et al., 2010). Furthermore, Améglio et al. (2004) reported the catabolism of starch into sugars and the subsequent efflux from parenchymal cells to the vessels in late winter during the recovery of Juglans regia from cavitation induced by the winter freeze-thaw. Likewise, the reported differences between the capacities to reverse embolisms in angiosperms and conifers (Johnson et al., 2012; Brodersen and McElrone, 2013; Meinzer et al., 2013) are likely associated with the differences in sapwood NSC content between these two groups reported by Hoch et al. (2003). This empirical evidence suggests that NSC reserves in wood parenchymal cells play a key role in determining the hydraulic strategies of plants, because species with high NSC and parenchymal fractions would have a higher resilience to cavitation and thus could withstand a certain loss of hydraulic conductivity.

Finally, conifers and angiosperms also differ in cell anatomy and wood density (Table 2), and several studies suggest functional implications for these traits in climate-induced responses. For example, wood density has been proposed as a good predictor of the resistance of the xylem to drought stress, because species with denser wood tend to have a higher resistance to cavitation (Jacobsen et al., 2007; Pratt et al., 2007). Moreover, Ogasa et al. (2013) found a negative correlation between wood density and xylem recovery in deciduous angiosperm trees (Salix, Betula, Carpinus, Cerasus), suggesting in turn a negative association between increased cavitation resistance and resilience of xylem function. Wood density in Mediterranean evergreen shrubs was also negatively correlated with the percentage of parenchymal area in the xylem (Jacobsen et al., 2007). This correlation is 
consistent with the higher capacity of xylems to recover in species with wood of lower density reported by Ogasa et al. (2013), because living xylem parenchyma may be involved in the reversal of embolisms (Bucci et al., 2003; Brodersen et al., 2010; Nardini et al., 2011; Zufferey et al., 2011; Brodersen and McElrone, 2013). In addition, low wood density has been associated with high capacitance (Pratt et al., 2007; Sperry et al., 2008; McCulloh et al., 2012). In water-stressed plants, a higher capacitance facilitates the transient release of water stored in living wood cells to the conduit lumen, increasing xylem water potential (Meinzer et al., 2009; Barnard et al., 2011; Zhang et al., 2011).

The higher resistance of conifers to both freeze-thaw and drought-induced cavitation (Sperry and Sullivan, 1992; Wang et al., 1992; Choat et al., 2012) has also been associated with differences in wood anatomy (Table 2). The main difference in wood anatomy between angiosperms and gymnosperms is that the latter have tracheids that also provide mechanical strength (Hacke et al., 2001; Poorter et al., 2012). In particular, thick conduit walls providing mechanical strength have been suggested as the factor limiting the size of tracheids in conifers (Pittermann et al., 2006). Small tracheids are less prone to freeze-thaw cavitation in conifers (Tyree and Zimmermann, 1988; Sperry and Sullivan, 1992; Pittermann and Sperry, 2003), as are small vessels in angiosperms (Sperry and Sullivan, 1992), in which other woody cells such as fibers are responsible for mechanical support of the plant. In both groups, however, no direct relationship has been found between conduit size and drought-induced cavitation across species. Pit membrane area, though, must be limited (as it is where air-seeding develops) to achieve a certain level of safety from drought-induced cavitation, which in turn limits the surface area and thus the size of conduit cells (Hacke et al., 2006; Jansen et al., 2009; Brodribb et al., 2012).

We hypothesize that the reported trait differences between conifers and angiosperms (Table 2) constitute two different strategies that may imply qualitatively different growth responses to increased temperatures and drought in the Mediterranean region. The different stomatal responses to heat waves and summer droughts, inducing drought-avoidance strategies and stomatal closure in conifers, would be key to determining these different growth responses (Martínez-Ferri et al., 2000; Coll et al., 2013; Poyatos et al., 2013). Critically, the higher sensitivity of the stomatal conductance to increases in VPD in conifers may promote near-zero assimilation rates and may strongly limit carbon uptake and photosynthesis over extended periods (Martínez-Ferri et al., 2000; Johnson et al., 2012; Meinzer et al., 2013; Poyatos et al., 2013). Summer drought may strongly affect carbon dynamics and NSC mobilization and consumption in both conifers and angiosperms, for example by enhancing the catabolism of starch to soluble sugars for increasing xylem tension and sap osmolarity (Sala et al., 2012), mobilizing NSCs for embolism repair, producing soluble sugars to stabilize cellular proteins and membranes, stopping cell division and tree growth favoring in turn the accumulation of photosynthates in starch (Peñuelas and Estiarte, 1998; Estiarte and Peñuelas, 1999; Körner, 2003) or promoting increased allocation of NSCs in roots and declines in fine-root biomass (Anderegg, 2012). Even though the coupled effect of these complex processes on the carbon balance of the tree may be quite variable (species and site specific), we suggest that early stomatal closure and the associated larger reductions of assimilation rates in conifers may consistently produce a more negative impact on both carbon balance and growth responses of trees.

On the other hand, increased winter temperatures can reduce the costs associated with the impacts of freeze-thaw embolism and may also differently affect the carbon balance of angiosperms and conifers. Critically, angiosperms have a higher sensitivity to freeze-thaw embolism (Table 2) and may experience higher costs. This group could thus benefit more from increased winter temperatures. Higher winter temperatures would thereby entail fewer freeze-thaw cavitations, which are responsible for the almost complete loss of hydraulic conductivity in ring-porous species and for the partial loss in diffuse-porous species by late winter (Sperry and Sullivan, 1992). The restoration of water transport in angiosperms is achieved by the production of earlywood or by vessel refilling, which have carbon demands supplied by NSCs (Barbaroux and Bréda, 2002; Epron et al., 2012; Michelot et al., 2012). In contrast, since the xylems of conifers are highly resistant to freeze-thaw cavitation (Sperry and Sullivan, 1992; Brodribb et al., 2012), this group may not have very different NSC costs for the restoration of water transport after mild or cold winters.

Winter temperature is a major driver for switching carbon allocation either to storage or to growth and respiration (Epron et al., 2012; Körner, 2013) and for the conditioning accumulation of starch (Oleksyn et al., 2000). When temperature is too low for growth, carbon assimilation is still significant, so NSCs derived from winter photosynthesis are mainly allocated to storage during cold periods (Rossi et al., 2008; Fajardo et al., 2012). In addition, the catabolism of starch into soluble carbohydrates during cold periods may possibly maintain intracellular osmotic concentration, which is positively correlated with cold hardiness (Cavender-Bares et al., 2005; Morin et al., 2007). In both conifers and angiosperms, increased winter temperatures are likely to alter cambium activation, growth allocation and the dynamic balance among winter photosynthesis, starch storage, and soluble sugar concentrations.

Finally, increased winter, spring and autumn temperatures can significantly influence phenological responses, advancing winter cambium activation, spring bud burst and leaf unfolding or delaying autumn leaf fall (Peñuelas and Filella, 2001). The derived extension of the phenological period could have strong effects on tree height and growth (Vitasse et al., 2009a,b, 2013; Lenz et al., 2012). Both the phenological cycles and the growth-associated carbon dynamics, however, are qualitatively different in conifers, ring-porous deciduous trees, diffuse-porous deciduous trees, and evergreen oaks (Epron et al., 2012; Table 3). These differences suggest that these groups may qualitatively differ in the relative effects of increased spring temperatures on carbon dynamics and tree growth. For example, an increase in temperature early in the growing season may also increase vessel diameter in deciduous angiosperms but not in conifers (Matisons and Brumelis, 2012).

\section{PHENOLOGY (HYPOTHESIS 1.2)}

An average lengthening of the growing season of about 11 days has been detected in Europe from the early 1960s to the end of the twentieth century (Menzel and Fabian, 1999; Peñuelas and Filella, 

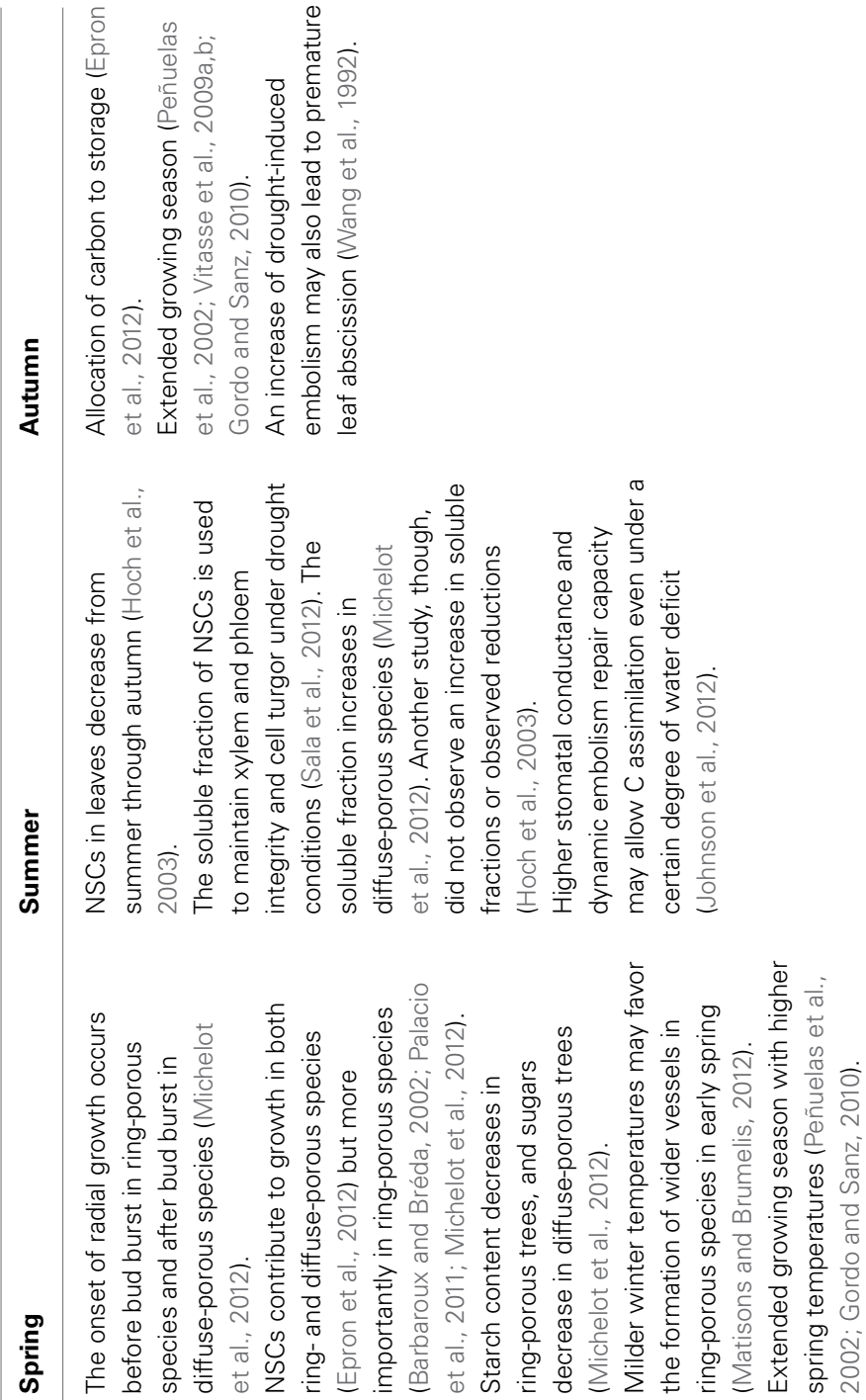

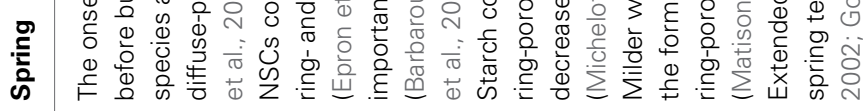

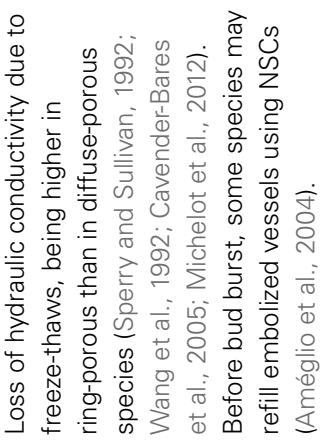

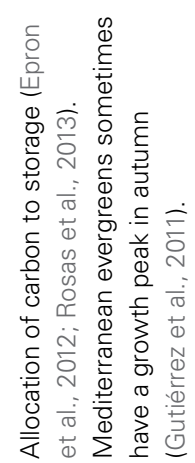

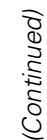

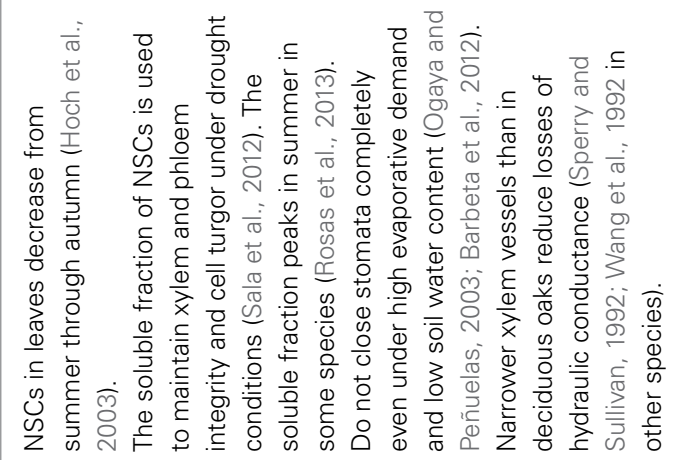

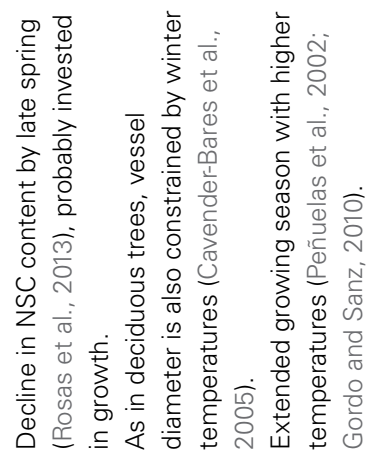

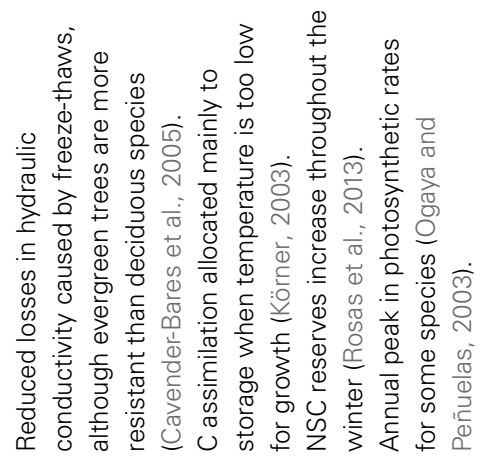




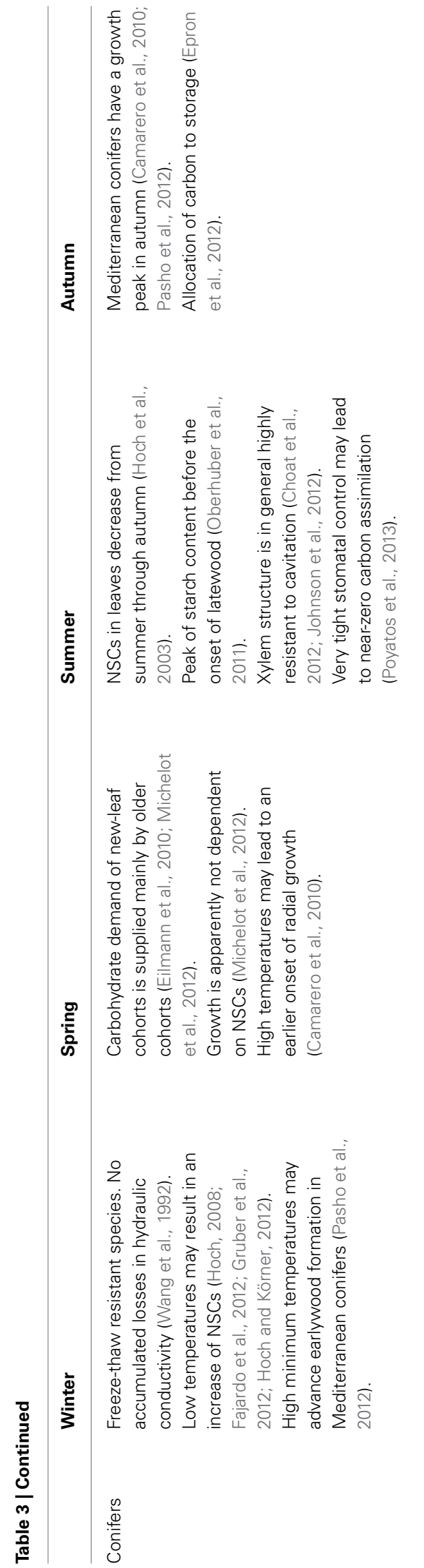

2001; Linderholm, 2006; Menzel et al., 2006). Growing season length has a strong effect on tree productivity, Consequently, the reported temperature-induced changes in phenology could affect tree growth responses (White et al., 1999; Kramer et al., 2000; Picard et al., 2005; Delpierre et al., 2009; Richardson et al., 2009; Vitasse et al., 2009a,b; Dragoni et al., 2011; Rossi et al., 2011; Lugo et al., 2012). Empirical evidence in temperate trees suggests that the productivity of evergreen needleleaf forests is less sensitive to phenology than is productivity of deciduous broadleaf forests (Welp et al., 2007; Delpierre et al., 2009; Richardson et al., 2010). For instance, Churkina et al. (2005) reported a different sensitivity of net ecosystem productivity to growing season length in deciduous forests $\left(5.8+0.7 \mathrm{~g} \mathrm{C} \mathrm{m}^{-2} \mathrm{~d}^{-1}\right)$, compared with evergreen needleleaf forests $\left(3.4+0.3 \mathrm{~g} \mathrm{C} \mathrm{m}^{-2} \mathrm{~d}^{-1}\right)$. Similarly, Piao et al. (2007) reported different sensitivities of gross ecosystem productivity to growing season length $\left(9.8+2.6 \mathrm{~g} \mathrm{C} \mathrm{m}^{-2}\right.$ $\mathrm{d}^{-1}$ in deciduous forests, compared with $4.9+2.5 \mathrm{~g} \mathrm{C} \mathrm{m}^{-2} \mathrm{~d}^{-1}$ in evergreen needleleaf forests). To our knowledge, it remains untested whether qualitatively different phenology responses in Mediterranean conifers and angiosperm trees may occur and translate into different tree growth responses on a large scale.

However, other evidence points to complex and speciesspecific effects of phenology on tree growth. For instance, for both conifer and angiosperm trees, a variety of species-specific responses in bud burst and bud set have been reported along altitudinal and latitudinal gradients, reporting both advances, delays and non-significant clines (Vitasse et al., 2009a,b, 2013; Alberto et al., 2013). For example, depending on the species considered, Vitasse et al. (2009b) found positive and negative correlations between advanced leaf emergence and annual growth. Moreover, warming can produce complex and counter-intuitive effects on phenology and growth. For example, strong warming in winter could slow the fulfillment of chilling requirements, which may delay spring phenology and growth (Körner and Basler, 2010; Yu et al., 2010) and affect differently early and late successional species (Körner and Basler, 2010).

In the Mediterranean region, mean annual and maximum temperatures have been identified as the major drivers of deciduous tree phenology (Gordo and Sanz, 2010). However, the effects of temperature on the phenology of many conifer and angiosperm tree species in the Mediterranean basin remain yet relatively poorly quantified (Maseyk et al., 2008). It remains also uncertain whether trade-offs between the advance of spring flushing date and the increased risk of frost damage may differ qualitatively between Mediterranean trees (Lockhart, 1983; Lechowicz, 1984). The same applies for trade-offs between delayed autumn leaf fall date, increased autumn photosyntate storage, and increased late-autumn frost damage risk and incomplete leaf nutrient remobilization costs (Lim et al., 2007). Finally, in the Mediterranean basin, drought periods significantly affect both leaf phenology and tree growth in both conifer and angiosperm trees (de Luis et al., 2007, 2011; Camarero et al., 2010). For instance, increased leaf retention rate and lifespan have been observed in response to drought in holm oak forests (Bussotti et al., 2003; Misson et al., 2010). Drought also causes foliage to fall earlier and results in incomplete leaf nutrient translocation and increased nutrient concentration in litter (Martínez-Alonso et al., 2007). 


\section{INTRA-SPECIFIC COMPETITION, INTER-SPECIFIC COMPETITION AND FOREST SUCCESSION (HYPOTHESIS 1.3)}

Empirical studies reveal that intra-specific competition acts as a major determinant of growth patterns in Mediterranean forests in both conifer and angiosperm trees (Gómez-Aparicio et al., 2011). Forest densification due to land abandonment and the advance of succession is occurring over extensive areas, increasing competition, reducing tree growth, and increasing mortality (Gómez-Aparicio et al., 2011; Vilà-Cabrera et al., 2011; Coll et al., 2013). Coll et al. (2013) reported much higher negative effects of forest stand basal area on conifer growth than in angiosperm trees in both dry and wet extremes of a large-scale rainfall gradient, and these trends were paralleled by higher effects of basal area on small-tree mortality observed in conifers. These results coincide with studies revealing oaks less sensitive to competition than pines in this area (Sánchez-Gómez et al., 2008; Gómez-Aparicio et al., 2011).

Inter-specific competition also plays an important role in determining growth responses in Mediterranean conifer and angiosperm trees. Specifically, large-scale surveys suggest that small-sized conifers are more sensitive to growth suppression by late successional species (Gómez-Aparicio et al., 2011; Zavala et al., 2011; Coll et al., 2013). Angiosperm trees are significantly expanding their distributional ranges, increasing recruitment across extensive areas (Coll et al., 2013; Vayreda et al., 2013). Morover, during the last decades the expansion of the dominant angiosperm tree Quercus ilex has negatively influenced the recruitment success of five Pinus species on a large scale in this area (Carnicer et al., 2013a).

\section{SIZE, AGE, AND ALLOMETRY (HYPOTHESIS 1.4)}

Mediterranean conifers differ from angiosperm trees in their allometrical relationships between tree size (diameter at breast height) and crown growth variables (Poorter et al., 2012). The peak of crown growth is generally reached at lower sizes in conifers, which also show a much steeper decrease with size than broadleaved species (Poorter et al., 2012). These different allometric relationships are in turn associated with several other traits (maximal height, crown size, shade tolerance, wood density, apical dominance) and also interact with local habitat aridity (Poorter et al., 2012). Similarly, Gómez-Aparicio et al. (2011) reported that in Iberian forests competitive effects for conifers scale approximately quadratically with diameter at breast height $\left(\mathrm{dbh}^{2}\right)$ and linearly for broadleaved trees. To our knowledge, it remains untested whether these different allometric relationships might be related to the contrasting tree growth responses to temperature reported in Mediterranean conifers and angiosperm trees (Gómez-Aparicio et al., 2011).

\section{DROUGHT AND TEMPERATURE (HYPOTHESIS 1.5)}

Large-scale studies demonstrate that drought and increased temperatures significantly limit tree growth in xeric regions of the Mediterranean basin (Andreu et al., 2007; Martínez-Alonso et al., 2007; Sarris et al., 2007; Bogino and Bravo, 2008; Martínez-Vilalta et al., 2008; Gómez-Aparicio et al., 2011; Vilà-Cabrera et al., 2011; Candel-Pérez et al., 2012; Sánchez-Salguero et al., 2012; Vayreda et al., 2012; Coll et al., 2013) and produce qualitatively different ecophysiological responses in Mediterranean conifers and angiosperm trees (Martínez-Ferri et al., 2000; Zweifel et al., 2007; Eilmann et al., 2009). For instance, while drought often results in early stomatal closure in Mediterranean conifers (Martínez-Ferri et al., 2000; Klein et al., 2011; Poyatos et al., 2013), angiosperm trees are able to maintain substantial transpiration levels during summer drought events (Quero et al., 2011).

Drought largely determines cambium growth in Mediterranean forests, producing plastic and seasonally variable patterns, ranging from one single annual peak to markedly bimodal trends (Maseyk et al., 2008; Camarero et al., 2010; de Luis et al., 2011). However, large-scale studies in the Iberian peninsula reveal that competition effects on growth are often stronger than drought effects (Gómez-Aparicio et al., 2011; Coll et al., 2013). Nevertheless, strong interactions between competition and drought effects have been reported, and significantly increase at the edge of climatic gradients (Linares et al., 2010; Vayreda et al., 2012; Coll et al., 2013; Ruiz-Benito et al., 2013). Finally, there is also some evidence of individual predispositions to winter-drought induced tree dieback in P. sylvestris (Voltas et al., 2013), local adaptation for water use efficiency in $P$. halepensis (Voltas et al., 2008), and correlations of temperature and genetic variability at candidate loci for drought tolerance in $P$. halepensis and P. pinaster (Grivet et al., 2011), suggesting important interactions between individual adaptive traits and drought impacts.

\section{WINTER FREEZING (HYPOTHESIS 1.6)}

Angiosperm trees are more vulnerable to freeze-thaw embolism and this may contribute to explain the dominance of conifer trees at high altitudes (Cavender-Bares et al., 2005; Brodribb et al., 2012) and could in turn result in qualitatively different growth responses in conifers and angiosperm trees. For example, Gómez-Aparicio et al. (2011) reported that Atlantic deciduous broadleaved trees in the Iberian peninsula had lower competitive response ability at lower temperatures, in contrast to mountain conifer species. In this study, tree growth of Atlantic deciduous broadleaved trees was negatively affected by low temperatures (Gómez-Aparicio et al., 2011). In line with this, several studies have demonstrated that low winter temperatures directly inhibit cell division and tree growth in cold localities (Körner, 1998, 2013; Fajardo et al., 2012).

\section{INTERACTIONS BETWEEN MULTIPLE FACTORS (HYPOTHESIS 1.7)}

Tree growth patterns in the Iberian peninsula have several contributing drivers that interact along geographical gradients (Coll et al., 2013). For instance, Gómez-Aparicio et al. (2011) studied tree growth responses in 15 tree species in Spain and reported that sensitivity to competition increased with decreasing precipitation in all species. Notably, the best predictive models for tree growth in Gómez-Aparicio et al. (2011) included interactions between size, competitive effects and climate variables. Similarly, Coll et al. (2013) modeled growth responses in the Iberian peninsula and reported a significant increase in the strength of interactions between tree size, tree height and climate variables at the drier and wetter edges of rainfall gradients. These interactions 
could increase with ongoing climate change, and several studies suggest that warming could increase competition for water in Mediterranean forests (Linares et al., 2010).

\section{LOCAL ADAPTATION, INDIVIDUAL- AND PROVENANCE VARIATION (HYPOTHESIS 1.8)}

Local selection processes may affect the adaptive traits determining the different growth responses to temperature observed in Iberian conifers and angiosperm trees. For example, provenance studies in both conifer and angiosperm trees have revealed genetic differences in growth rates and other growth-related traits (age at reproduction, timing of bud burst and bud set, leaf traits, flowering phenology), suggesting that populations are often adapted to their local conditions of temperature and water availability (Rehfeldt, 1978, 1982, 1988; Borghetti et al., 1993; Climent et al., 2008; Mátyás et al., 2009; Rose et al., 2009; Ramírez-Valiente et al., 2010, 2011; Santos et al., 2010; Chmura et al., 2011; Robson et al., 2012; Alberto et al., 2013). In provenance trial studies, populations from cold environments often cease growth earlier, while populations from warm localities generally grow faster (Alberto et al., 2013). Notably, local selection for increased growth rates may induce lower resistance to drought and frost. For instance, in conifers fast-growing provenances often exhibit lower cold hardiness and/or lower resistance to drought stress (Hannerz et al., 1999; Cregg and Zhang, 2001; Chuine et al., 2006). These differences have been attributed to trade-offs between resistance to frost and drought and growth (Chuine et al., 2006 and see Martin St Paul et al., 2012).

\section{PHENOTYPIC PLASTICITY (HYPOTHESIS 1.9)}

Mediterranean trees show strong plastic responses in tree growth patterns, which are associated with seasonal climate variability (e.g., Camarero et al., 2010; de Luis et al., 2011). Critically, phenology and growth plasticity responses differ between provenances and species and may determine observed demographic and evolutionary responses to global warming (Nicotra et al., 2010). For example, low elevation provenances often exhibit greater phenological plasticity to temperature than high elevation provenances (Vitasse et al., 2013) and this could in turn influence observed tree growth responses. To our knowledge, it remains untested whether Mediterranean conifers exhibit higher growth plasticity than angiosperm trees, although it has been reported that Iberian conifers show higher growth rates than angiosperm trees in absence of competition (Gómez-Aparicio et al., 2011; Poorter et al., 2012).

\section{EXPERIMENTAL ASSESSMENT OF THE RELATIVE CONTRIBUTION OF THE HYPOTHESES}

The available empirical evidence suggest that several factors interact and seem to determine contrasting growth responses to temperature in Mediterranean conifer and angiosperm trees. Therefore, improved experimental approaches are required to quantitatively assess the relative importance of these factors. While several experimental and observational approaches could be applied, we suggest that reciprocal provenance trial experiments may be especially suited for this purpose. Previous studies assert that multiple common garden experiments located in latitudinal and altitudinal gradients are particularly relevant to study phenology and growth responses to temperature (Reich and Oleksyn, 2008; Vitasse et al., 2010). Furthermore, the inclusion of different provenances in these reciprocal experiments allows the quantification of environmentally induced phenotypic plasticity, genotypic variance and their interaction (e.g., Vitasse et al., 2013). Complementarily, drought effects on growth could be studied by manipulative experiments combined with reciprocal common garden designs (reviewed in Klein et al., 2011; Wu et al., 2011). Similarly, the effects of intra- and inter-specific competition could be studied manipulating tree densities and composition in different experimental groups. Finally, to assess tree size effects and allometric relationships, the study of saplings of different ages would be required. Alternatively, long-term experiments could provide also relevant information to quantify allometric relationships. Finally, in all these experimental designs, the periodic measurement of ecophysiological traits should be implemented to assess their seasonal variation and their putative role in determining growth responses.

\section{COMPLEX AND MULTIPLE EFFECTS OF TEMPERATURE AND DROUGHT ON TREE PHYSIOLOGY}

Climate produces multiple and complex effects on tree physiology. As highlighted in Table 1, we expect that multiple physiological processes can simultaneously react to the changes in environmental temperatures and influence growth responses. For example, temperature and drought directly affect several ecophysiological processes such as carbon and nutrient uptake, carbon allocation between tissues, photosynthesis, respiration, processes of embolism prevention and repair, phenological cycles, cambium reactivation, cell division and expansion or carbon transfer rates (Körner, 1998; Bréda et al., 2006; Rennenberg et al., 2006; Sanz-Pérez et al., 2009; Camarero et al., 2010; Epron et al., 2012; Michelot et al., 2012). Moreover, these direct climatic effects on tree physiology can in turn produce secondary indirect effects, for example the promotion of signaling and regulatory responses, acclimation and phenotypically plastic responses or changes in gene expression (reviewed in Peñuelas et al., 2013b). Table 4 provides a brief, non-exhaustive description of the diverse effects of temperature and drought on tree physiology. It is important to bear in mind that all these ecophysiological processes often have different sensitivities and thresholds to temperature and water deficit. For example, tree growth and cambium activation are more sensitive to low temperatures than is photosynthesis (Körner, 1998; Fajardo et al., 2012). In addition, as shown in Table 4, responses to climate are often species or tissue specific or depend on developmental stage and seasonal phase and can be influenced by regulatory feedbacks that can often imply multi-tissue coordinated responses. Despite the overwhelming complexity and diversity of the effects of temperature and drought reported in Table 4, several studies have demonstrated consistent differences between major plant groups, such as conifers and angiosperms, in climate-induced responses (e.g., Way and Oren, 2010; Gómez-Aparicio et al., 2011; Coll et al., 2013). 
Table 4 | A non-exhaustive and synthetic review of the different effects of temperature (A) and drought (B) on different tree physiological processes.

\section{References}

\section{(A) EFFECTS OF TEMPERATURE ON TREE PHYSIOLOGY}

Photosynthesis. Temperatures higher/lower than the optimum decrease photosynthesis and affect multiple biochemical processes. For example, high temperatures can reduce the efficiency of electron transport in the thylakoid membrane of chloroplasts, which in turn down-regulate the content of ribulose-1,5-bisphosphate and deactivate Rubisco. High temperatures also inhibit Rubisco activase, due to their low thermal optimum. The solubility of the two substrates of Rubisco, $\mathrm{CO}_{2}$, and $\mathrm{O}_{2}$, is differentially affected by temperature, stimulating photorespiration and inhibiting photosynthesis at high temperatures.

Photosystem II is also sensitive to high temperatures, which stimulate mechanisms to avoid photo-oxidation and membrane denaturation, such as isoprene production and the xanthophyll cycle.

Low temperatures cause a variety of physiological and acclimative responses, including modifications in the structure of the thylakoid membrane in chloroplasts, alleviation of photoinhibition through upregulation of carbon metabolism and increased synthesis of storage carbohydrates, increased production of antioxidants, prevention of intracellular freezing by increased soluble carbohydrates (mobilization of starch to sucrose) and changes in gene expression and signaling pathways.

The growth environment of plants determines the temperature optimum of photosynthesis. In warmer environments, plants acclimate to increase the thermal optimum of the maximum carboxylation velocity (Vcmax) and the maximum potential rate of electron transport (Jmax).

\author{
Above the thermal optimum for photosynthesis, the emission of biogenic volatile organic compounds such as \\ Above the thermal optimum for photosynthesis, the emission of biogenic volatile organic compounds such as
isoprene and monoterpenes progressively increases.
}

Leaf respiration is strongly affected by temperature, increasing at high temperatures (e.g., above $35-40^{\circ} \mathrm{C}$ ) and peaking at higher temperatures than photosynthesis.

High temperatures often increase net primary production and plant growth. In cold-adapted trees, photosynthesis is less sensitive to low temperatures than is tree growth (cell division and growth, cambium activation). In alpine treelines, new tissue formation is nearly absent at temperatures around $5^{\circ} \mathrm{C}$, but considerable rates of photosynthesis are maintained between 0 and $10^{\circ} \mathrm{C}$.

Higher temperatures influence foliar phenology, promoting earlier bud burst and delaying leaf fall.
Rennenberg et al., 2006

Morin et al., 2007

Kattge and Knorr, 2007

Chaves et al., 2012

Flexas et al., 2012; Sharkey and

Bernacchi, 2012

In the absence of drought, temperature often increases nutrient-uptake capacity $\left(\mathrm{NH}_{4}^{+}, \mathrm{NO}_{3}^{-}, \mathrm{PO}_{43}^{-}, \mathrm{K}^{+}\right)$.

Temperature can also increase both xylem loading of amino compounds and nitrogen allocation in aboveground tissues.

Llusià and Peñuelas, 2000;

Rennenberg et al., 2006

Rennenberg et al., 2006; Smith and Dukes, 2013

Körner, 1998; Way and Oren, 2010; Wu et al., 2011; Fajardo et al., 2012; Lenz et al., 2012

Peñuelas and Filella, 2001; Peñuelas et al., 2002; Vitasse et al., 2009a,b, 2013

Rennenberg et al., 2006

Freezing causes cell dehydration, formation of ice in intracellular spaces and embolism. Buds are more resistant than leaves to frost.

Temperature, in absence of drought, positively affects rates of soil respiration and litter decomposition.

Organs, individuals, life stages and species consistently differ in their phenological responses to temperature and sensitivity to damage from frost and drought.

Morin et al., 2007; Augspurger, 2009

\section{Wu et al., 2011}

Niinemets and Valladares, 2006; Morin et al., 2007; Augspurger, 2009

\section{(B) EFFECTS OF DROUGHT ON TREE PHYSIOLOGY}

Photosynthesis. Drought limits photosynthesis by stomatal closure, diffusion limitations in the mesophyll and metabolic impairment. It can also limit photosynthesis via secondary effects, such as reduced hydraulic conductance and oxidative stress.

Drought activates diverse signaling pathways associated with stomatal closure. For example, it modifies abscisic acid (ABA) signaling in leaves, shoots and roots; increases xylem-sap pH and changes aquaporin concentrations, leaf hydraulic conductance signals and electric signals.

Drought reduces osmotic potential in the soil and predawn leaf water potentials and limits water uptake. To maintain water uptake, plants increase the production of osmolites, down-regulate electron flux and increase the activity of antioxidant enzymes. Drought can also increase the degradation of foliar proteins and the concentration of soluble amino acids and NSCs in the leaves, which may act in turn as osmoprotectants to stabilize proteins and membranes. Drought also promotes an increase in the concentrations of soluble antioxidants.
Chaves et al., 2012

Sharkey and Bernacchi, 2012
Rennenberg et al., 2006. 


\begin{tabular}{|c|c|}
\hline & References \\
\hline \multicolumn{2}{|l|}{ (B) EFFECTS OF DROUGHT ON TREE PHYSIOLOGY } \\
\hline $\begin{array}{l}\text { Severe water stress can produce irreversible or persistent damage in the photosynthetic apparatus of leaves } \\
\text { (relative to leaf lifespan). }\end{array}$ & Sharkey and Bernacchi, 2012 \\
\hline Drought reduces tree growth, net primary production, cambium activity, cell division and growth. & $\begin{array}{l}\text { Eilmann et al., 2009; Camarero } \\
\text { et al., 2010; Wu et al., 2011; de } \\
\text { Luis et al., } 2011\end{array}$ \\
\hline Drought reduces $\mathrm{C}$ transfer rates. & $\begin{array}{l}\text { Barthel et al., 2011; Epron } \\
\text { et al., } 2012\end{array}$ \\
\hline Drought is associated with acclimative responses such as mid-term reductions in total leaf area and defoliation. & $\begin{array}{l}\text { Bréda et al., 2006; Ogaya and } \\
\text { Peñuelas, 2006; Carnicer et al., } \\
2011\end{array}$ \\
\hline Drought promotes an increase in NSCs in roots and a decrease in fine-root biomass. & $\begin{array}{l}\text { Anderegg, 2012; Anderegg } \\
\text { et al., } 2012\end{array}$ \\
\hline
\end{tabular}

Drought alters nutrient-uptake processes, for example promoting increases in ammonification and decreases in denitrification in the soil.

Gessler et al., 2005

Isoprenoid emissions can be negatively affected by drought stress and increase during plant recovery after drought.

Rennenberg et al., 2006;

Peñuelas and Staudt, 2010

Drought can increase the accumulation of ethylene in shoots, in turn reducing shoot growth.

Chaves et al., 2012

Water deficit can reduce $\mathrm{N}$ uptake from the soil and change $\mathrm{N}$ partitioning between roots and shoots, increasing $\mathrm{N}$

Rennenberg et al., 2006

content in the roots.

Omic studies reveal that drought produces changes in gene regulation, for example promoting proline synthesis and down-regulating proline degradation.

Chaves et al., 2012; Peñuelas et al., 2013a

Chaves et al., 2012

Negative effects of drought differ between phases of plant development and annual phenophases and are usually stronger during reproductive and leaf-emergence phases in deciduous trees.

Drought produces tissue-specific signaling responses in roots, shoots and leaves and tissue-specific interactions between signaling factors. For example, different interactions between ABA and ethylene have been reported in roots and shoots.

\section{EMPIRICAL PATTERNS IN THE IBERIAN PENINSULA: THE NEGATIVE SYNERGISTIC EFFECTS OF INCREASED TEMPERATURES AND FOREST SUCCESSIONAL ADVANCE}

In the Mediterranean basin, land use changes often negatively interact with increased temperatures and drought events and result, in diverse taxonomic groups, in negative demographic trends detectable on a large scale (Linares et al., 2010; Stefanescu et al., 2011; Carnicer et al., 2013b). In the case of Iberian forests, increased stand competition due to forest successional advance and forest densification has been identified as a major driver of tree demographic responses (Gómez-Aparicio et al., 2011; Carnicer et al., 2013a). Notably, stand competition interacts with temperature and drought responses in this region, especially in the drier and wetter edges of rainfall gradients (Linares et al., 2010; Coll et al., 2013). In this section we briefly review the contrasting demographic trends to temperature observed in Conifers and Angiosperm trees in the Iberian peninsula. Forest succession is currently favoring a shift toward an increased dominance of angiosperm trees on a large scale (Carnicer et al., 2013a; Coll et al., 2013; Vayreda et al., 2013). On top of this, recent studies (Gómez-Aparicio et al., 2011; Coll et al., 2013) show that tree growth responses to temperature differ between conifers and angiosperms on a large scale in the Mediterranean forests of the Iberian Peninsula. Large-scale empirical patterns of the responses of tree growth to temperature along a gradient of rainfall in Spain are illustrated in Figure 1A, showing contrasting responses in conifers (black dots) and angiosperms (gray dots). Panel (A) depicts the variation of temperature beta estimates on species-specific responses of tree growth in forests located along a gradient of rainfall (Coll et al., 2013). Treegrowth data were obtained from the Spanish National Forest Inventory, which comprises a wide range of forest types, from typically Mediterranean lowland stands to northern temperate forests with strong Atlantic influences to alpine forests located in the Pyrenees (Coll et al., 2013). To analyze the relationship between growth responses to temperature and trait differences between conifers and angiosperms, we used hydraulic safety margins as a key synthetic variable of the hydraulic strategy of each species (Figure 1B). Panel (B) depicts two separate linear regressions between the temperature beta estimates 
on growth and the species-specific hydraulic safety margins. Hydraulic safety margins were obtained from Cochard and Tyree (1990), Cochard (1992, 2006), Tognetti et al. (1998), Cochard et al. (1999), Martínez-Vilalta and Piñol (2002), Martínez-Vilalta et al. (2002, 2009), Oliveras et al. (2003), Corcuera et al. (2006), and Choat et al. (2012). A significant linear relationship between growth responses to temperature and species-specific hydraulic safety margins was only observed in angiosperms (Figure 1B), and conifers had significantly larger hydraulic safety margins (Figure 1B). Across the studied range of hydraulic safety margins, the temperature beta estimates were positive for angiosperms (gray dots) but negative for conifers (black dots), regardless of mean precipitation (Figure 1A). This result is consistent with those of other studies on the effects of climate in the Iberian Peninsula reporting negative significant effects of temperature on

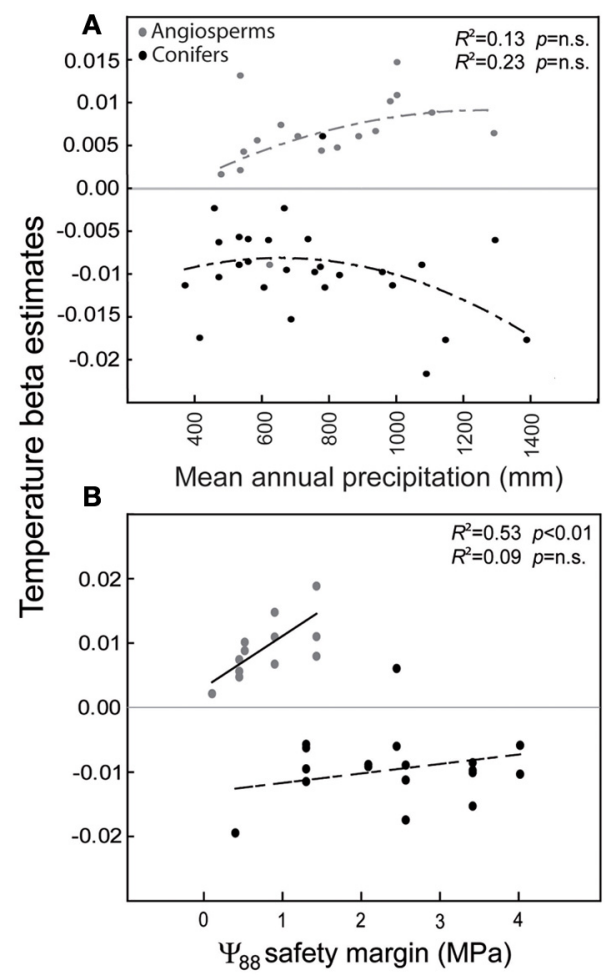

FIGURE 1 | Summary of the variation in the effect of temperature on tree growth along a rainfall gradient (A) and across interspecific differences in hydraulic safety margins (B) in conifers (black dots) and angiosperms (gray dots). The tree species included in the analysis are: Fagus sylvatica, Quercus ilex, Q. pubescens, Q. pyrenaica, Q. robur, Abies alba, Pinus halepensis, P. nigra, P. pinaster, P. pinea, P. sylvestris, and $P$. uncinata. $P$. radiata and $Q$. suber were only included in panel $(\mathbf{A})$ due to a lack of data for hydraulic safety margins. Coll et al. (2013) applied generalized linear models (GLM) to study tree growth responses (dependent variable) and assessed the following independent predictors: (i) climate and topography (Emberger water deficit index, mean annual temperature, terrain slope), (ii) forest stand structure (tree density, basal area), (iii) soil (organic layer depth), (iv) individual tree traits [tree height, diameter at breast height (DBH)], and (v) management practices (e.g., plantations). Beta estimates in panels (A) and (B) show the reported significant effects of temperature on tree growth in GLM analyses (Coll et al., 2013). n.s. means not significant. tree growth in conifers (Gómez-Aparicio et al., 2011; CandelPérez et al., 2012; Büntgen et al., 2013). Figure 2 illustrates the specific forest successional context in which the reported contrasting effects of temperature on tree growth previously reported occur. Conifers show a significantly higher percentage of plots characterized by recruitment failure (Figure 2A; Carnicer et al., 2013a). In contrast, Quercus species showed a much larger percentage of recently colonized plots and/or resprouting areas (i.e., plots without adult trees but in which recruits and/or resprouts of the focal species were detected, Figure 2B, Carnicer et al., 2013a). Overall Figures 1, 2 suggest that in this area the negative effects of warming and forest successional advance could synergistically impact conifer species during the next decades.

\section{DISCUSSION}

We have reviewed the different hypotheses that may contribute to explain the recently reported different growth responses to

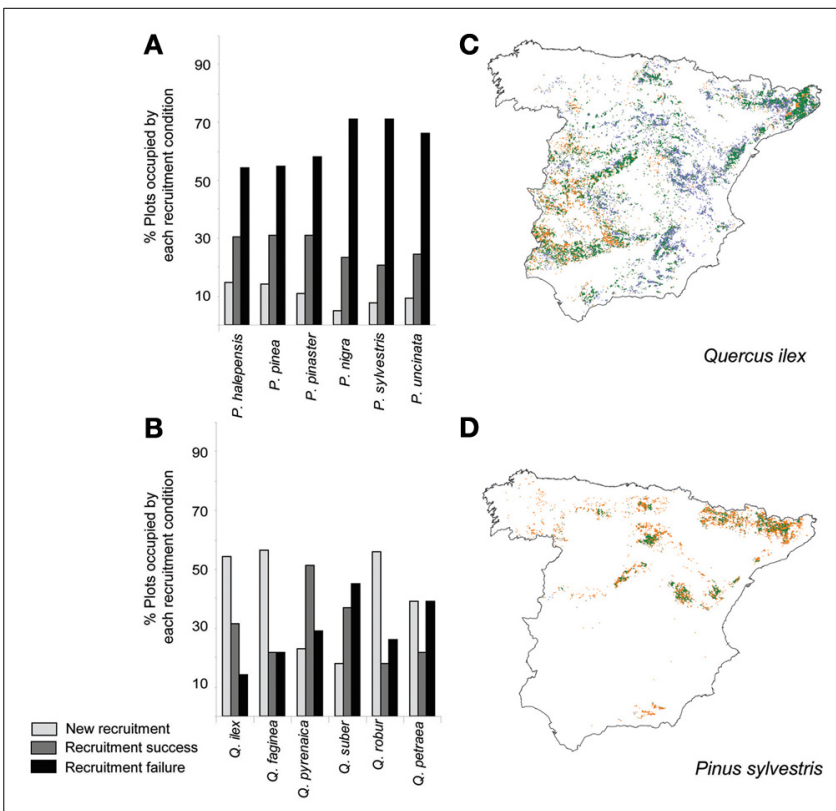

FIGURE 2 | Contrasting large-scale trends in tree recruitment observed in the Iberian peninsula for small saplings (height $<30 \mathrm{~cm}$ ) in Conifers (Pinus) and Angiosperm trees (Quercus). (A) Variation in the percentage of plots with recruitment success (gray), recruitment failure (black) and new recruitment areas (plots without adult trees of the focal species in which small recruits or resprouts were detected) in Pinus species; (B) Variation in the percentage of plots with recruitment success (gray), recruitment failure (black) and new recruitment areas in Quercus species. (C) Spatial trends in recruitment for the dominant species Quercus ilex. Blue areas indicate new recruitment areas (i.e., areas with recruits but absence of adult trees), orange areas illustrate recruitment failure and green areas illustrate recruitment success (i.e., areas characterized by the presence of both adult and small saplings). (D) Spatial trends in recruitment for Pinus sylvestris. Differences between recruitment trends in Pinus and Quercus were significant (see Carnicer et al., 2013a for a detailed statistical test. Average proportion of plots with recruitment failure: $F=16.64, P=0.002$; average proportion of plots with new recruitment: $F=35.04, P=0.0001$ ). Data were obtained from the Spanish National Forest Inventory, consisting in a regular grid of circular plots at a density of $1 \mathrm{plot} / \mathrm{km}^{2}$. 
temperature in Mediterranean angiosperm and conifer trees (Table 1; Gómez-Aparicio et al., 2011; Coll et al., 2013). Conifer and angiosperm trees differ in the effects of phenology on tree productivity, in their sensitivity to stand competition and in their growth allometry. In addition, they consistently differ in an integrated suite of key traits, including different hydraulic safety margins, stomatal sensitivity, embolism repair capacity and xylem anatomy, suggesting two contrasting ecophysiological strategies to confront drought and extreme temperature events. However, for many Mediterranean conifer and angiosperm trees, detailed empirical studies contrasting the relative effect on tree growth of the factors listed in Table 1 are still lacking. For example, it is not clear whether temperature-induced shifts in phenology consistently differ between conifers and angiosperm trees in the Mediterranean region and how these shifts in phenology could differentially alter their productivity. Similarly, the seasonal dynamics of key traits, like cambium growth, tissue NSC content or sap flow, remain yet poorly quantified for many species. So it is clear that improved experimental approaches to contrast and assess the relative effect of the reviewed hypotheses are required (Table $\mathbf{1}$ ) if we are to explain the contrasting growth trends reported in recent large-scale studies in these two groups (Gómez-Aparicio et al., 2011; Coll et al., 2013; Figure 1). We have suggested that the relative effects of these factors (Table 1) could be contrasted in reciprocal common garden experiments located in altitudinal or latitudinal gradients that provide an ideal design to estimate temperature effects on phenology and growth, and also allow the estimation of local adaptation and phenotypic plasticity (Vitasse et al., 2009a,b, 2013). In these reciprocal transplant experiments, detailed quantitative analysis of the relationships between growth measures and hydraulic safety margins, stomatal sensitivities to VPD, embolism repair activity and NSC carbon dynamics in wood parenchyma and other tissues would be ideally required to clarify the relative importance of these processes and their dynamic inter-relationships (Camarero et al., 2010; de Luis et al., 2011; Oberhuber et al., 2011; Michelot et al., 2012; Pasho et al., 2012).

The available empirical evidence (Gómez-Aparicio et al., 2011; Coll et al., 2013; Figure 2) suggests that increased stand competition associated with successional advance is a primary driver of growth trends in the forests of the Iberian peninsula. So it would be key to simulate this factor in the proposed transplant experiments, manipulating sapling densities and composition. We suggest that mixed pine-oak designs would be especially interesting because recent studies describe the widespread expansion of Quercus saplings and resprouts in the Iberian peninsula and limited recruitment in Pinus species (Carnicer et al., 2013a; Coll et al., 2013; Vayreda et al., 2013; Figure 2). Moreover, Quercus ilex seems to act as a keystone species in driving these limited recruitment trends, inhibiting recruitment in five different Pinus species (Rouget et al., 2001; Carnicer et al., 2013a). In addition, several studies report that pines are more sensitive to competition and their growth can be largely suppressed with the advance of succession, specially on sapling and young stages (e.g., Gómez-Aparicio et al., 2011; Zavala et al., 2011; Coll et al., 2013). Therefore, these processes should be ideally considered in reciprocal transplant experiments, to allow the experimental study of the combined negative synergistic effects of warming and increased successional advance.

Ideally, the experimental approaches tested in these common garden experiments should simulate future forest scenarios in the face of climate change in the Iberian Peninsula. However, future scenarios in this region remain uncertain. For example, the available model predictions vary from important range contractions to substantial range expansions (Benito Garzón et al., 2011; Keenan et al., 2011; Ruiz-Labourdette et al., 2012; García-Valdés et al., 2013). We have suggested a possible scenario of global change dominated by the widespread expansion of angiosperm broadleaved trees, increased suppression of pine growth and recruitment by $Q$. ilex and specially acute negative demographic trends in mountain pines (Pinus sylvestris, Pinus nigra and, to a less extent, $P$. uncinata) (Figure 2; Carnicer et al., 2013a). Other major uncertainties in future forest scenarios are related to nonlinear dynamics in fire activity (Loepfe et al., 2012), changes in fire-climate relationships motivated by the generalized advance of forest succession and the expansion of Quercus species that may substantially alter the distribution of forest fuel over extensive areas (Pausas and Paula, 2012; Carnicer et al., 2013a), and the future changes in land uses induced by shifts in global energy policies and the increased use of forests as a local energy source (Peñuelas and Carnicer, 2010; Carnicer and Peñuelas, 2012).

In Table 3 we have also discussed how tree carbon dynamics may be interacting with climate-induced responses in the seasonal variation of photosynthesis, annual growth cycles, embolism prevention, embolism repair and refilling and stomatal responses. Important gaps in our knowledge remain, and we lack a clear picture of how tissue-specific NSC concentrations vary seasonally, their interspecific variation and how these seasonal variations are connected to the diverse physiological functions examined (i.e., carbon buffer function, winter- and droughtinduced embolism repair, embolism prevention, bud burst and leaf unfolding, responses of root and stem growth and respiration) (Hoch et al., 2003; Epron et al., 2012; Michelot et al., 2012; Sala et al., 2012). Another aspect that merits more attention in future empirical tests is the putative existence of compensatory dynamics across seasons in the effects of climate on tree physiology. For example, higher temperatures may reduce the costs of winter embolism in broadleaved deciduous trees, lengthen the growing season or increase the production of photosynthates in spring. These changes could in turn allow higher NSC storage in spring, which could increase embolism repair capacity during summer droughts (compensatory seasonal effects).

In summary, a review of the existing empirical evidence suggests that contrasting demographic responses in Mediterranean conifer and angiosperm trees are currently occurring, due to both widespread forest successional advance and to divergent growth responses to temperature. Trait-based differences in these two groups may contribute to explain their different responses to temperature (Table 2, Figure 1) 
and their different role during successional processes in this region (Figure 2, Table 2, reviewed in Zavala et al., 2011; Poorter et al., 2012; Sheffer, 2012). Reciprocal common garden experiments may offer a very promising tool to develop integrative tests of the diverse factors reviewed (Table 1) and to simulate the synergistic negative effects of forest successional advance and climate warming on conifer species (Carnicer et al., 2013a).

\section{REFERENCES}

Alberto, F. J., Aitken, S. N., Alía, R., González-Martínez, S. C., Hänninen, H., Kremer, A., et al. (2013). Potential for evolutionary responses to climate change - evidence from tree populations. Glob. Chang. Biol. 19, 1645-1661. doi: $10.1111 /$ gcb. 12181

Améglio, T., Decourteix, M., Alves, G., Valentin, V., Sakr, S., Julien, J.-L., et al. (2004). Temperature effects on xylem sap osmolarity in walnut trees: evidence for a vitalistic model of winter embolism repair. Tree Physiol. 24, 785-793. doi: 10.1093/treephys/24.7.785

Anderegg, W. R. (2012). Complex aspen forest carbon and root dynamics during drought. Clim. Change 111, 983-991. doi: 10.1007/ s10584-012-0421-9

Anderegg, W. R. L., Berry, J. A., Smith, D. D., Sperry, J. S., Anderegg, L. D. L., and Field, C. B. (2012). The roles of hydraulic and carbon stress in a widespread climateinduced forest die-off. Proc. Natl. Acad. Sci. U.S.A. 109, 233-237. doi: 10.1073/pnas.1107891109

Andreu, L., Gutiérrez, E., Macias, M., Ribas, M., Bosch, O., and Camarero, J. J. (2007). Climate increases regional tree-growth variability in Iberian pine forests. Glob. Change Biol. 13, 804-815. doi: 10.1111/j. 1365-2486.2007.01322.x

Augspurger, C. K. (2009). Spring 2007 warmth and frost: phenology, damage and refoliation in a temperate deciduous forest. Funct. Ecol. 23, 1031-1039. doi: 10.1111/j.13652435.2009.01587.x

Bale, J. S., Masters, G. J., Hodkinson, I. D., Awmack, C., Bezemer, T. M., Brown, V. K., et al. (2002). Herbivory in global climate change research: direct effects of rising temperature on insect herbivores. Glob. Change Biol. 8, 1-16. doi: $\quad$ 10.1046/j.1365-2486.2002. 00451.x

Barbaroux, C., and Bréda, N. (2002). Contrasting distribution and seasonal dynamics of carbohydrate reserves in stem wood of adult ring-porous sessile oak and diffuse-porous beech trees. Tree Physiol. 22, 1201-1210. doi: 10.1093/treephys/22.17.1201

Barbeta, A., Ogaya, R., and Peñuelas, J. (2012). Comparative study of diurnal and nocturnal sap flow of Quercus ilex and Phillyrea latifolia in a Mediterranean holm oak forest in Prades (Catalonia, NE Spain). Trees 26, 1651-1659. doi: 10.1007/s00468-012-0741-4

Barbeta, A., Ogaya, R., and Peñuelas, J. (2013). Dampening effects of long-term experimental drought on growth and mortality rates of a Holm oak forest. Glob. Change Biol. 19, 3133-3144. doi: $10.1111 / \mathrm{gcb}$. 12269

Barnard, D. M., Meinzer, F. C. Lachenbruch, B., McCulloh, K. A., Johnson, D. M., and Woodruff, D. R. (2011). Climate-related trends in sapwood biophysical properties in two conifers: avoidance of hydraulic dysfunction through coordinated adjustments in xylem efficiency, safety and capacitance. Plant Cell Environ. 34, 643-654. doi: 10.1111/j.1365-3040.2010.02269.x

Barthel, M., Hammerle, A., Sturm, P., Baur, G., Gentsch, L., and Knohl, A. (2011). The diel imprint of leaf metabolism on the $\delta 13$ signal of soil respiration under control and drought conditions. New Phytol. 192, 925-938. doi: 10.1111/j.14698137.2011.03848.x

Benito Garzón, M., Alía, R., Robson, T. M., and Zavala, M. A. (2011). Intra-specific variability and plasticity influence potential tree species distributions under climate change. Glob. Ecol. Biogeogr. 20, 766-778. doi: 10.1111/j.1466-8238.2010.00646.x

Bogino, S. M., and Bravo, F. (2008). Growth response of Pinus pinaster Ait. to climatic variables in central Spanish forests. Ann. For. Sci. 65, 506. doi: 10.1051/forest:2008025

Borghetti, M., Leonardi, S., Raschi, A., Snyderman, D., and Tognetti, R. (1993). Ecotypic variation of xylem embolism, phenological traits, growth parameters and

\section{ACKNOWLEDGMENTS}

This research was supported by VENI-NWO 863.11.021, BES2011-043314 and 2010 BP_A 00091 grants and the Spanish Government projects CGC2010-17172 and Consolider Ingenio Montes (CSD2008-00040) and by the Catalan Government project SGR 2009-458. Jofre Carnicer, Adrià Barbeta and Dominik Sperlich contributed equally to the manuscript and share first authorship.

allozyme characteristics in Fagus sylvatica. Funct. Ecol. 7, 71-720. doi: $10.2307 / 2390193$

Bréda, N., Huc, R., Granier, A., and Dreyer, R. (2006). Temperate forest trees and stands under severe drought: a review of ecophysiological responses, adaptation processes and long-term consequences. Ann. For. Sci. 63, 625-644. doi: 10.1051/forest:2006042

Brodersen, C. R., and McElrone, A. J. (2013). Maintenance of xylem network transport capacity: a review of embolism repair in vascular plants. Front. Plant Sci. 4:108. doi: 10.3389/fpls. 2013.00108

Brodersen, C. R., McElrone, A. J. Choat, B., Matthews, M. A., and Shackel, K. A. (2010). The dynamics of embolism repair in xylem: in vivo visualizations using highresolution computed tomography. Plant Physiol. 154, 1088-1095. doi: 10.1104/pp.110.162396

Brodribb, T. J., Bowman, D. J. M S., Nichols, S., Delzon, S., and Burlett, R. (2010). Xylem function and growth rate interact to determine recovery rates after exposure to extreme water deficit. New Phytol. 188, 533-542. doi: 10.1111/j.14698137.2010.03393.x

Brodribb, T. J., Pittermann, J., and Coomes, D. A. (2012). Elegance versus speed: examining the competition between conifer and angiosperm trees. Int. J. Plant Sci. 173, 673-694. doi: 10.1086/666005

Bucci, S. J., Scholz, F. G., Goldstein, G., Meinzer, F. C., and Sternberg, L. D. S. L. (2003). Dynamic changes in hydraulic conductivity in petioles of two savanna tree species: factors and mechanisms contributing to the refilling of embolized vessels. Plant Cell Environ. 26, 1633-1645. doi: 10.1046/j.01407791.2003.01082.x

Büntgen, U., Martínez-Peña, F., Aldea, J., Rigling, A., Fischer, E. M., Camarero, J. J., et al. (2013). Declining pine growth in Central Spain coincides with increasing diurnal temperature range since the 1970s. Glob.
Planet. Change 107, 177-185. doi: 10.1016/j.gloplacha.2013.05.013

Bussotti, F., Borghini, F., Celesti, C. Leonzio, C., Cozzi, A., Bettini, D., et al. (2003). Leaf shedding, crown condition and element return in two mixed holm oak forests in Tuscany, central Italy. For. Ecol. Manage. 176, 273-285. doi: 10.1016/S03781127(02)00283-9

Camarero, J. J., Olano, J. M., and Parras, A. (2010). Plastic bimodal xylogenesis in conifers from continental Mediterranean climates. New Phytol. 185, 471-480. doi: 10.1111/j.1469-8137.2009.03073.x

Candel-Pérez, D., Linares, J. C., Viñegla, B., and Lucas-Borja, M. E. (2012). Assessing climate-growth relationships under contrasting stands of co-occurring Iberian pines along an altitudinal gradient. For. Ecol. Manage. 274, 48-57. doi: 10.1016/j.foreco.2012.02.010

Carnicer, J., Brotons, L., Stefanescu, C., and Peñuelas, J. (2012). Biogeography of species richness gradients: linking adaptive traits, demography and diversification. Biol. Rev. Camb. Philos. Soc. 87, 457-479. doi: 10.1111/j.1469-185X.2011.00210.x

Carnicer, J., Coll, M., Ninyerola, M., Pons, X., Sánchez, G., and Peñuelas, J. (2011). Widespread crown condition decline, food web disruption, and amplified tree mortality with increased climate change-type drought. Proc. Natl. Acad. Sci. U.S.A. 108, 1474-1478. doi: 10.1073/pnas.1010070108

Carnicer, J., Coll, M., Ninyerola, M., Pons, X., Vayreda, J., and Peñuelas, J. (2013a). Large-scale recruitment limitation in Mediterranean pines: the role of Quercus ilex and forest successional advance as key regional drivers. Glob. Ecol. Biogeogr. doi: 10.1111/geb.12111

Carnicer, J., Stefanescu, C., Vila, R. Dincã, V., Font, X., and Peñuelas, J. (2013b). A unified framework for diversity gradients: the adaptive trait continuum. Glob. Ecol. Biogeogr. 22, 6-18. doi: 10.1111/j.1466-8238.2012.00762.x 
Carnicer, J., and Peñuelas, J. (2012). The world at a crossroads: financial scenarios for sustainability. Energy Policy 48, 611-617. doi: 10.1016/j.enpol.2012.05.065

Cavender-Bares, J., Cortes, P., Rambal, S., Joffre, R., Miles, B., and Rocheteau, A. (2005). Summer and winter sensitivity of leaves and xylem to minimum freezing temperatures: a comparison of co-occurring Mediterranean oaks that differ in leaf lifespan. New Phytol. 168, 597-612. doi: $\quad 10.1111 / j .1469-8137.2005$. 01555.x

Chave, J., Coomes, D., Jansen, S., Lewis, S. L., Swenson, N. G., and Zanne, A. E. (2009). Towards a worldwide wood economics spectrum. Ecol. Lett. 12, 351-366. doi: 10.1111/j. 1461-0248.2009.01285.x

Chaves, M., Flexas, J., Gulías, J., Loreto, F., and Medrano, H. (2012). "Photosyntesis under water deficits, flooding and salinity," in Terrestrial Photosyntesis in a Changing Environment, eds J. Flexas, F. Loreto, and H. Medrano (New York, NY: Cambridge University Press), 299-311. doi: 10.1017/CBO 9781139051477.024

Chmura, D. J., Anderson, P. D., Howe, G. T., Harrington, C. A., Halofsky, J. E., Peterson, D. L., et al. (2011). Forest responses to climate change in the northwestern United States: ecophysiological foundations for adaptive management. For. Ecol. Manage. 261, 1121-1142. doi: 10.1016/j.foreco. 2010.12.040

Choat, B., Jansen, S., Brodribb, T. J., Cochard, H., Delzon, S., Bhaskar, R., et al. (2012). Global convergence in the vulnerability of forests to drought. Nature 491, 752-755. doi: 10.1038/nature1 1688

Chuine, I., Rehfeldt, G. E., and Aitken, S. N. (2006). Height growth determinants and adaptation to temperature in pines: a case study of Pinus contorta and Pinus monticola. Can. J. For. Res. 36, 1059-1066. doi: 10.1139/x06-005

Churkina, G., Schimel, D., Braswell, B. H., and Xiao, X. M. (2005). Spatial analysis of growing season length control over net ecosystem exchange. Glob. Change Biol. 11, 1777-1787. doi: 10.1111/j.13652486.2005.001012.x

Climent, J., Prada, M. A., Calama, R., Chambel, M. R., De Ron, D. S., and Alía, R. (2008). To grow or to seed: ecotypic variation in reproductive allocation and cone production by young female Aleppo pine (Pinus halepensis, Pinaceae). Am. J.
Bot. 95, 833-842. doi: 10.3732/ajb. 2007354

Cochard, H. (1992). Vulnerability of several conifers to air embolism. Tree Physiol. 11, 73-83. doi: 10.1093/treephys/11.1.73

Cochard, H. (2006). Cavitation in trees. Physique 7, 1018-1126. doi: 10.1016/j.crhy.2006.10.012

Cochard, H., Lemoine, D., and Dreyer, E. (1999). The effects of acclimation to sunlight on the xylem vulnerability to embolism in Fagus sylvatica L. Plant Cell Environ. 22, 101-108. doi: 10.1046/j.1365-3040.1999.00367.x

Cochard, H., and Tyree, M. T. (1990). Xylem dysfunction in Quercus: vessel sizes, tyloses, cavitation and seasonal changes in embolism. Tree Physiol. 6, 393-407. doi: 10.1093/treephys/6.4.393

Coll, M., Peñuelas, J., Ninyerola, M., Pons, X., and Carnicer, J. (2013). Multivariate effect gradients driving forest demographic responses in the Iberian Peninsula. For. Ecol. Manage. 303, 195-209. doi: 10.1016/j.foreco.2013.04.010

Corcuera, L., Camarero, J. J., Sisó, S., and Gil-Pelegrín, E. (2006). Radialgrowth and wood-anatomical changes in overaged Quercus pyrenaica coppice stands: functional responses in a new Mediterranean landscape. Trees 20, 91-98. doi: 10.1007/s00468-005-0016-4

Cregg, B. M., and Zhang, J. W. (2001). Physiology and morphology of Pinus sylvestris seedlings from diverse sources under cyclic drought stress. For. Ecol. Manage. 154, 131-139. doi: 10.1016/S03781127(00)00626-5

Delpierre, N., Soudani, K., Francois, C., Kostner, B., Pontailler, J. Y., Nikinmaa, E., et al. (2009). Exceptional carbon uptake in European forests during the warm spring of 2007: a data-model analysis. Glob. Change Biol. 15, 1455-1474. doi: 10.1111/j.13652486.2008.01835.x

de Luis, M., Grièar, J., Èufar, K., and Raventós, J. (2007). Seasonal dynamics of wood formation in Pinus halepensis from dry and semiarid ecosystems in Spain. IAWA J. 28, 389-404.

de Luis, M., Novak, K., Raventós, J., Grièar, J., Prislan, P., and Eufar, K. (2011). Cambial activity, wood formation and sapling survival of Pinus halepensis exposed to different irrigation regimes. For. Ecol. Manage. 262, 1630-1638. doi: 10.1016/j.foreco.2011.07.013

Dragoni, D., Schmid, H. P., Wayson, C. A., Potter, H., Grimmond, C. S. B., and Randolph, J. C. (2011),
Evidence of increased net ecosystem productivity associated with a longer vegetated season in a deciduous forest in south-central Indiana, USA. Glob. Change Biol. 17, 886-897. doi: 10.1111/j.13652486.2010.02281.x

Eilmann, B., Buchmann, N., Siegwolf, R., Saurer, M., Cherubini, P., and Rigling, A. (2010). Fast response of Scots pine to improved water availability reflected in tree-ring width and 813C. Plant Cell Environ. 33, 1351-1360. doi: 10.1111/j.13653040.2010.02153.x

Eilmann, B., Zweifel, R., Buchmann, N., Fonti, P., and Rigling, A. (2009). Drought-induced adaptation of the xylem in Scots pine and pubescent oak. Tree Physiol. 29, 1011-1020. doi: 10.1093/treephys/tpp035

Epron, D., Bahn, M., Derrien, D. Lattanzi, F. A., Pumpanen, J. Gessler, A., et al. (2012). Pulselabelling trees to study carbon allocation dynamics: a review of methods, current knowledge and future prospects. Tree Physiol. 32, 776-798. doi: 10.1093/treephys/ tps057

Estiarte, M., and Peñuelas, J. (1999). Excess carbon: the relationship with phenotypical plasticity in storage and defense functions of plants. Orsis 14, 159-203.

Fajardo, A., Piper, F. I., Pfund, L., Körner, C., and Hoch, G. (2012). Variation of mobile carbon reserves in trees at the alpine treeline ecotone is under environmental control. New Phytol. 195, 794-802. doi 10.1111/j.1469-8137.2012.04214.x

Flexas, J., Loreto, F., and Medrano, $\mathrm{H}$. (2012). Terrestrial Photosyntesis in a Changing Environment. Cambridge: Cambridge University Press. doi: 10.1017/CBO9781139051477

Galiano, L., Martínez-Vilalta, J., Sabaté, S., and Lloret, F. (2012). Determinants of drought effects on crown condition and their relationship with depletion of carbon reserves in a Mediterranean holm oak forest. Tree Physiol. 32, 478-489. doi: 10.1093/treephys/ tps025

García-Valdés, R., Zavala, M. A., Araújo, M. B., and Purves, D. W. (2013). Chasing a moving target: projecting climate change-induced shifts in non-equilibrial tree species distributions. J. Ecol. 101, 441-453. doi: 10.1111/1365-2745.12049

Gessler, A., Jung, K., Gasche, R., Papen, H., Heidenfelder, A., Börner, E., et al. (2005). Climate and forest management influence nitrogen balance of European beech forests: microbial $\mathrm{N}$ transformations and inorganic $\mathrm{N}$ net uptake capacity of mycorrhizal roots. Eur. J. For. Res. 124, 95-111. doi: 10.1007/s10342005-0055-9

Gómez-Aparicio, L., García-Valdés, R., Ruíz-Benito, P., and Zavala, M. A. (2011). Disentangling the relative importance of climate, size and competition on tree growth in Iberian forests: implications for forest management under global change. Glob. Change Biol. 17, 2400-2414. doi: 10.1111/j.1365-2486.2011.02421.x

Gordo, O., and Sanz, J. J. (2010). Impact of climate change on plant phenology in Mediterranean ecosystems. Glob. Change Biol. 16, 1082-1106. doi: 10.1111/j.13652486.2009.02084.x

Grivet, D., Sebastiani, F., Alía, R., Bataillon, T., Torre, S., ZabalAguirre, M., et al. (2011). Molecular footprints of local adaptation in two Mediterranean conifers. Mol. Biol. Evol. 28, 101-116. doi: $10.1093 / \mathrm{molbev} / \mathrm{msq} 190$

Gruber, A., Pirkebner, D., Florian, C., and Oberhuber, W. (2012). No evidence for depletion of carbohydrate pools in Scots pine (Pinus sylvestris L.) under drought stress. Plant Biol. (Stuttg.) 14, 142-148. doi: 10.1111/j.1438-8677.2011.00467.x

Gutiérrez, E., Campelo, F., Camarero, J., Ribas, M., Muntán, E., Nabais, C., et al. (2011). Climate controls act at different scales on the seasonal pattern of Quercus ilex L. stem radial increments in NE Spain. Trees Struct. Funct. 25, 637-646. doi: 10.1007/s00468-011-0540-3

Hacke, U. G., and Sperry, J. S. (2003). Limits to xylem refilling under negative pressure in Laurus nobilis and Acer negundo. Plant Cell Environ. 26, 303-311. doi: 10.1046/j.13653040.2003.00962.x

Hacke, U. G., Sperry, J. S., Pockman, W. T., Davis, S. D., and McCulloh, K. A. (2001). Trends in wood density and structure are linked to prevention of xylem implosion by negative pressure. Oecologia 126, 457-461. doi: 10.1007/s004420100628

Hacke, U. G., Sperry, J. S., Wheeler, J. K., and Castro, L. (2006). Scaling of angiosperm xylem structure with safety and efficiency. Tree Physiol. 26, 689-701. doi: 10.1093/treephys/26.6.689

Hannerz, M., Aitken, S. N., King, J., and Budge, S. (1999). Effects of genetic selection for growth on frost hardiness in western hemlock. Can. J. For. Res. 29, 509-516. doi: 10.1139/ x99-019

Hoch, G. (2008). The carbon supply of Picea abies trees at a 
Swiss montane permafrost site. Plant Ecol. Divers. 1, 13-20. doi: 10.1080/17550870802230791

Hoch, G., and Körner, C. (2012). Global patterns of mobile carbon stores in trees at the high elevation tree line. Glob. Ecol. Biogeogr. 21, 861-871. doi: 10.1111/j.14668238.2011.00731.x

Hoch, G., Richter, A., and Körner, C. (2003). Non-structural carbon compounds in temperate forest trees. Plant Cell Environ. 26, 1067-1081. doi: 10.1046/j.00168025.2003.01032.x

Jacobsen, A. L., Agenbag, L., Esler, K. J., Pratt, R. B., Ewers, F. W., and Davis, S. D. (2007). Xylem density, biomechanics and anatomical traits correlate with water stress in 17 evergreen shrub species of the Mediterraneantype climate region of South Africa. J. Ecol. 95, 171-183. doi: 10.1111/j. 1365-2745.2006.01186.x

Jansen, S., Choat, B., and Pletsers, A. (2009). Morphological variation of intervessel pit membranes and implications to xylem function in angiosperms. Am. J. Bot. 96, 409-419. doi: 10.3732/ajb.0800248

Jensen, K. H., Liesche, J., Bohr, T., and Schulz, A. (2012). Universality of phloem transport in seed plants. Plant Cell Environ. 35, 1065-1076. doi: 10.1111/j.1365-3040.2011.02472.x

Johnson, D. M., McCulloh, K. A., Woodruff, D. R., and Meinzer, F. C. (2012). Hydraulic safety margins and embolism reversal in stems and leaves: why are conifers and angiosperms so different. Plant Sci. 195, 48-53. doi: 10.1016/j.plantsci. 2012.06.010

Kattge, J., and Knorr, W. (2007). Temperature acclimation in a biochemical model of photosynthesis: a reanalysis of data from 36 species. Plant Cell Environ. 30, 1176-1190. doi: $\quad 10.1111 /$ j.1365-3040.2007. 01690.x

Keenan, T., Serra, J. M., Lloret, F., Ninyerola, M., and Sabaté, S. (2011). Predicting the future of forests in the Mediterranean under climate change, with niche- and process-based models: $\mathrm{CO} 2$ matters! Glob. Change Biol. 17, 565-579. doi: $\quad 10.1111 /$ j.1365-2486.2010. 02254.x

Klein, T., Cohen, S., and Yakir, D. (2011). Hydraulic adjustments underlying drought resistance of Pinus halepensis. Tree Physiol. 31, 637-648. doi: 10.1093/treephys/ tpr047

Körner, C. (1998). A re-assessment of high elevation treeline positions and their explanation.
Oecologia 115, 445-459. doi: 10.1007/s004420050540

Körner, C. (2003). Carbon limitation in trees. J. Ecol. 91, 4-17. doi: 10.1046/j.1365-2745.2003.00742.x

Körner, C. (2013). Growth controls photosynthesis - mostly. Nova Acta Leopoldina 114, 273-283.

Körner, C., and Basler, D. (2010). Phenology under global warming. Science 327, 1461-1462. doi: 10.1126/science. 1186473

Kramer, K., Leinonen, I., Loustau, D. (2000). The importance of phenology for the evaluation of impact of climate change on growth of boreal, temperate and Mediterranean forests ecosystems: an overview. Int. J. Biometeorol. 44, 67-75. doi: 10.1007/s004840000066

Lechowicz, M. (1984). Why do temperate deciduous trees leaf out at different times. Adaptation and ecology of forest communities. Am. Nat. 124, 821-842. doi: 10.1086/284319

Lenz, A., Hoch, G., and Körner, C. (2012). Early season temperature controls cambial activity and total tree ring width at the alpine treeline. Plant Ecol. Divers 6, 365-375. doi: 10.1080/17550874.2012.711864

Lim, P. O., Kim, H. J., and Nam, H. G. (2007). Leaf senescence. Annu. Rev. Plant. Biol. 58, 115-136. doi: $\quad 10.1146 /$ annurev.arplant.57. 032905.105316

Linares, J. C., Camarero, J. J., and Carreira, J. A. (2010). Competition modulates the adaptation capacity of forests to climatic stress: insights from recent growth decline and death in relict stands of the Mediterranean fir Abies pinsapo. J. Ecol. 98, 592-603. doi: 10.1111/j.1365-2745.2010.01645.x

Linderholm, H. W. (2006). Growing season changes in the last century. Agric. For. Meteorol. 137, 1-14. doi: 10.1016/j.agrformet.2006.03.006

Llusià, J., and Peñuelas, J. (2000). Seasonal patterns of terpene content and emission from seven Mediterranean woody species in field conditions. Am. J. Bot. 87, 133-140. doi: 10.2307/2656691

Lockhart, J. A. (1983). Optimum growth initiation time for shoot buds of deciduous plants in a temperate climate. Oecologia 60, 34-37. doi: 10.1007/BF00379317

Loepfe, L., Martinez-Vilalta, J., and Piñol, J. (2012). Management alternatives to offset climate change effects on Mediterranean fire regimes in NE Spain. Clim. Change 115, 693-707. doi: 10.1007/s10584012-0488-3

Lugo, J. B., Deslauriers, A., and Rossi, S. (2012). Duration of xylogenesis in black spruce lengthened between 1950 and 2010 . Ann. Bot. 110, 1099-1108. doi: 10.1093/aob/mcs175

Lusk, C. H., Wright, I., and Reich, P. B. (2003). Photosynthetic differences contribute to competitive advantage of evergreen angiosperm trees over evergreen conifers in productive habitats. New Phytol. 160, 329-336. doi: 10.1046/j.14698137.2003.00879.x

Martínez-Alonso, C., Valladares, F., Camarero, J. J., Arias, M. L., and Serrano, M. (2007). The uncoupling of secondary growth, cone and litter production by intradecadal climatic variability in a Mediterranean Scots pine forest. For. Ecol. Manage. 253, 19-29. doi: 10.1016/j.foreco.2007.06.043

Martínez-Ferri, E., Balaguer, L., Valladares, F., Chico, J. M., and Manrique, E. (2000). Energy dissipation in drought-avoiding and drought-tolerant tree species at midday during the Mediterranean summer. Tree Physiol. 20, 131-138. doi: 10.1093/treephys/20.2.131

Martínez-Vilalta, J., and Piñol, J. (2002). Drought-induced mortality and hydraulic architecture in pine populations of the NE Iberian Peninsula. For. Ecol. Manage. 161, 247-256. doi: 10.1016/S0378-1127 (01)00495-9

Martínez-Vilalta, J., Prat, E., Oliveras, I., and Piñol, J. (2002). Xylem hydraulic properties of roots and stems of nine Mediterranean woody species. Oecologia 133, 19-29. doi: 10.1007/s00442-002-1009-2

Martínez-Vilalta, J., López, B. C., Adell, N., Badiella, L., and Ninyerola, M. (2008). Twentieth century increase of Scots pine radial growth in NE Spain shows strong climate interactions. Glob. Change Biol. 14, 2868-2881. doi: 10.1111/j.1365-2486.2008.01685.x

Martínez-Vilalta, J., Cochard, H., Mencuccini, M., Sterck, F., Herrero, A., Korhonen, J. F. J., et al. (2009). Hydraulic adjustment of Scots pine across Europe. New Phytol. 184, 353-364. doi: 10.1111/j.1469-8137. 2009.02954.x

Martin St Paul, N. K., Limousin, J.-M., Rodriguez-Calcerrada, J., Ruffault, J., Rambal, S., and Letts, M. G. (2012). Photosynthetic sensitivity to drought varies among populations of Quercus ilex along a rainfall gradient. Funct. Plant Biol. 39, 25-37. doi: 10.1071/FP11090

Maseyk, K. S., Lin, T., Rotenberg, E., Grünzweig, J. M., Schwartz, A., and Yakir, D. (2008). Physiologyphenology interactions in a productive semi-arid pine forest. New Phytol. 178, 603-616. doi: 10.1111/j.1469-8137.2008.02391.x

Matisons, R., and Brumelis, G. (2012). Influence of climate on tree-ring and earlywood vessel formation in Quercus robur in Latvia. Trees 26, 1251-1266. doi: 10.1007/s00468-012-0701-z

Mátyás, C., Bozic, G., Gömöry, D., Ivankovic, M., and Rasztovits, E. (2009). Juvenille growth response of European beech (Fagus sylvatica L.) to sudden change of climatic environment in SE European trials. iFor. Biogeosci. For. 2, 213-220. doi: 10.3832/ ifor0519-002

McCulloh, K. A., Johnson, D. M., Meinzer, F. C., Voelker, S. L. Lachenbruch, B., and Domec, J.-C. (2012). Hydraulic architecture of two species differing in wood density: opposing strategies in co-occurring tropical pioneer trees. Plant Cell Environ. 35, 116-125. doi: 10.1111/j.1365-3040.2011.02421.x

McDowell, N. G. (2011). Mechanisms linking drought, hydraulics, carbon metabolism, and vegetation mortality. Plant Physiol. 155, 1051-1059. doi: 10.1104/pp.110.170704

Meinzer, F. C., Johnson, D. M. Lachenbruch, B., McCulloh, K. A., and Woodruff, D. R. (2009). Xylem hydraulic safety margins in woody plants: coordination of stomatal control of xylem tension with hydraulic capacitance. Funct. Ecol. 23, 922-930. doi: 10.1111/j.1365-2435.2009.01577.x

Meinzer, F. C., and McCulloh, K A. (2013). Xylem recovery from drought-induced embolism: where is the hydraulic point of no return. Tree Physiol. 33, 331-334. doi: 10.1093/treephys/tpt022

Meinzer, F. C., Woodruff, D. R., Eissenstat, D. M., Lin, H. S., Adams, T. S., and McCulloh, K. A. (2013). Above- and belowground controls on water use by trees of different wood types in an eastern US deciduous forest. Tree Physiol. 33, 345-356. doi: 10.1093/treephys/tpt012

Menzel, A., and Fabian, P. (1999). Growing season extended in Europe. Nature 397, 659. doi: 10.1038/17709

Menzel, A., Sparks, T. H., Estrella, N., Koch, E., Aasa, A., Ahas, R. et al. (2006). European phenological response to climate change matches the warming pattern. Glob. Change Biol. 12, 1969-1976. doi: 10.1111/j.1365-2486.2006.01193.x

Michelot, A., Simard, S., Rathgeber, C., Dufrene, E., and Damesin, C. (2012). Comparing the intra-annual 
wood formation of three European species (Fagus sylvatica, Quercus petraea and Pinus sylvestris) as related to leaf phenology and nonstructural carbohydrate dynamics. Tree Physiol. 32, 1033-1045. doi: 10.1093/treephys/tps052

Millar, C. I. (1993). Impact of the Eocene on the evolution of Pinus. Ann. Mo. Bot. Gard. 80, 471-498. doi: $10.2307 / 2399795$

Misson, L., Limousin, J., Rodriguez, R., and Letts, M. G. (2010). Leaf physiological responses to extreme droughts in Mediterranean Quercus ilex forest. Plant Cell Environ. 33, 1898-1910. doi: 10.1111/j.1365-3040.2010.02193.x

Morin, X., Améglio, T., Ahas, R., KurzBesson, C., Lanta, V., Lebourgeois, F., et al. (2007). Variation in cold hardiness and carbohydrate concentration from dormancy induction to bud burst among provenances of three European oak species. Tree Physiol. 27, 817-825. doi: 10.1093/treephys/27.6.817

Nardini, A., Lo Gullo, M. A., and Salleo, S. (2011). Refilling embolized xylem conduits: is it a matter of phloem unloading. Plant Sci. 180, 604-611. doi: 10.1016/j.plantsci. 2010.12.011

Nardini, A., Tyree, M. T., and Salleo, S. (2001). Xylem cavitation in the leaf of Prunus laurocerasus and its impact on leaf hydraulics. Plant Physiol. 125, 1700-1709. doi: 10.1104/pp.125.4.1700

Nicotra, A. B., Atkin, O. K., Bonser, S. P., Davidson, A. M., Finnegan, E. J., Mathesius, U., et al. (2010). Plant phenotypic plasticity in a changing climate. Trends Plant Sci. 15, 684-692. doi: 10.1016/j.tplants.2010.09.008

Niinemets, Ü., Flexas, J., and Peñuelas, J. (2011). Evergreens favored by higher responsiveness to increased $\mathrm{CO}_{2}$. Trends Ecol. Evol. 26, 136-142. doi: 10.1016/j.tree.2010.12.012

Niinemets, Ü., and Valladares, F. (2006). Tolerance to shade, drought, and waterlogging of temperate Northern Hemisphere trees and shrubs. Ecol. Monogr. 76, 521-547. doi: 10.1890/00 12-9615(2006)076[0521:TTSDAW] 2.0.CO;2

Oberhuber, W., Swidrak, I., Pirkebner, D., and Gruber, A. (2011). Temporal dynamics of nonstructural carbohydrates and xylem growth in Pinus sylvestris exposed to drought. Can. J. For. Res. 41, 1590-1597. doi: 10. 1139/x11-084

Ogasa, M., Miki, N. H., Murakami, Y., and Yoshikawa, K. (2013).
Recovery performance in xylem hydraulic conductivity is correlated with cavitation resistance for temperate deciduous tree species. Tree Physiol. 33, 335-344. doi: 10.1093/treephys/tpt010

Ogaya, R., and Peñuelas, J. (2003). Comparative seasonal gas exchange and chlorophyll fluorescence of two dominant woody species in a Holm Oak Forest. Flora 198, 132-141. doi: 10.1078/03672530-00085

Ogaya, R., and Peñuelas, J. (2006). Contrasting foliar responses to drought in Quercus ilex and Phillyrea latifolia. Biol. Plant. 50, 373-382. doi: 10.1007/s10535-006-0052-y

Oleksyn, J., Zytkowiak, R., Karolewski, P., Reich, P. B., and Tjoelker, M. G. (2000). Genetic and environmental control of seasonal carbohydrate dynamics in trees of diverse Pinus sylvestris populations. Tree Physiol. 20, 837-847. doi: 10.1093/treephys/20.12.837

Oliveras, I., Martínez-Vilalta, J., Jimenez-Ortiz, T., Lledó, M. J., Escarré, A., and Piñol, J. (2003). Hydraulic properties of Pinus halepensis, Pinus pinea and Tetraclinis articulata in a dune ecosystem of Eastern Spain. Plant Ecol. 169, 131-141.

Palacio, S., Paterson, E., Sim, A., Hester, A. J., and Millard, P. (2011). Browsing affects intra-ring carbon allocation in species with contrasting wood anatomy. Tree Physiol. 31, 150-159. doi: 10.1093/treephys/tpq110

Pasho, E., Julio Camarero, J., and Vicente-Serrano, S. M. (2012). Climatic impacts and drought control of radial growth and seasonal wood formation in Pinus halepensis. Trees 26, 1875-1886. doi: 10.1007/s00468-012-0756-x

Pausas, J. G., and Paula, S. (2012). Fuel shapes the fire-climate relationship: evidence from Mediterranean ecosystems. Glob. Ecol. Biogeogr. 21, 1074-1082. doi: 10.1111/j.14668238.2012.00769.x

Peñuelas, J., and Carnicer, J. (2010). Climate change and peak oil: the urgent need for a transition to a non-carbon-emitting society. Ambio 39, 85-90. doi: 10.1007/s13280-009-0011-x

Peñuelas, J., and Estiarte, M. (1998). Can elevated $\mathrm{CO}_{2}$ affect secondary metabolism and ecosystem function? Trends Ecol. Evol. 13, 20-24. doi: 10.1016/S0169-5347 (97)01235-4

Peñuelas, J., and Filella, I. (2001). Phenology: responses to a warming world. Science 294, 793-795. doi: $10.1126 /$ science. 1066860

Peñuelas, J., Filella, I., and Comas, P. (2002). Changed plant and animal life cycles from 1952-2000 in the Mediterranean region. Glob. Change Biol. 8, 531-544. doi: 10.1046/j.1365-2486.2002.00489.x

Peñuelas, J., Lloret, F., and Montoya, R. (2013a). Severe drought effects on Mediterranean woody flora in Spain. For. Sci. 47, 214-218.

Peñuelas, J., Sardans, J., Estiarte, M., Ogaya, R., Carnicer, J., Coll, M. et al. (2013b). Evidence of current impact of climate change on life: a walk from genes to the biosphere. Glob. Change Biol. 19, 2303-2338. doi: $10.1111 / g c b .12143$

Peñuelas, J., and Staudt, M. (2010). BVOCs and global change. Trends Plant Sci. 15, 133-144. doi: 10.1016/j.tplants.2009.12.005

Piao, S. L., Friedlingstein, P., Ciais, P., Viovy, N., and Demarty, J. (2007). Growing season extension and its impact on terrestrial carbon cycle in the Northern Hemisphere over the past 2 decades. Glob. Biogeochem. Cycles 21, GB3018. doi: 10.1029/2006GB002888

Picard, G., Quegan, S., Delbart, N., Lomas, M. R., Le Toan, T., and Woodward, F. I. (2005). Phenology modelling in Siberia and its impact on the carbon budget. Glob. Change Biol. 11, 2164-2176. doi: 10.1111/j. 1365-2486.2005.01055

Pittermann, J., and Sperry, J. (2003). Tracheid diameter is the key trait determining the extent of freezinginduced embolism in conifers. Tree Physiol. 23, 907-914. doi: 10.1093/treephys/23.13.907

Pittermann, J., Sperry, J. S., Wheeler, J. K., Hacke, U. G., and Sikkema, E. H. (2006). Mechanical reinforcement of tracheids compromises the hydraulic efficiency of conifer xylem. Plant Cell Environ. 29, 1618-1628. doi: 10.1111/j.13653040.2006.01539.x

Poorter, L., Lianes, E., Moreno-de las Heras, M., and Zavala, M. A. (2012). Architecture of Iberian canopy tree species in relation to wood density, shade tolerance and climate. Plant Ecol. 213 707-722. doi: 10.1007/s11258-0120032-6

Poyatos, R., Aguadé, D., Galiano, L., Mencuccini, M., and MartínezVilalta, J. (2013). Drought-induced defoliation and long periods of near-zero gas exchange play a key role in accentuating metabolic decline of Scots pine. New Phytol. 200, 388-401. doi: 10.1111/nph. 12278
Pratt, R. B., Jacobsen, A. L., Ewers, F. W., and Davis, S. D. (2007). Relationships among xylem transport, biomechanics and storage in stems and roots of nine Rhamnaceae species of the California chaparral. New Phytol. 174, 787-798. doi: 10.1111/j.14698137.2007.02061.x

Quero, J. L., Sterck, F. J., MartínezVilalta, J., and Villar, R. (2011). Water-use strategies of six coexisting Mediterranean woody species during a summer drought. Oecologia 166, 45-57. doi: 10.1007/ s00442-011-1922-30

Ramírez-Valiente, J. A., SánchezGómez, D., Valladares, F., and Aranda, I. (2010). Phenotypic plasticity and local adaptation in leaf ecophysiological traits of thirteen contrasting cork oak populations under different water availabilities. Tree Physiol. 30, 618-627. doi: 10.1093/treephys/tpq013

Ramírez-Valiente, J. A., Valladares, F, Huertas, A. D., Granados, S., and Aranda, I. (2011). Factors affecting cork oak growth under dry conditions: local adaptation and contrasting additive genetic variance within populations. Tree Genet. Genomes 7, 285-295. doi: 10.1007/s11295-0100331-9

Rehfeldt, G. E. (1978). Genetic differentiation of Douglas fir populations from the northern Rocky Mountains. Ecology 59, 1264-1270. doi: 10.2307/1938240

Rehfeldt, G. E. (1982). Differentiation of Larix occidentalis populations from the northern Rocky Mountains. Silvae Genet. 31, 13-19.

Rehfeldt, G. E. (1988). Ecological genetics of Pinus contorta from the Rocky mountains (USA): a synthesis. Silvae Genet. 37, 131-135.

Reich, P. B., and Oleksyn, J. (2008). Climate warming will reduce growth and survival of Scots pine except in the far north. Ecol. Lett. 11, 588-597. doi: 10.1111/j.14610248.2008.01172.x

Rennenberg, H., Loreto, F., Polle, A., Brilli, F., Fares, S., Beniwal, R. S., et al. (2006). Physiological responses of forest trees to heat and drought. Plant Biol. 8, 556-571. doi: 10.1055/s-2006-924084

Richardson, A. D., Black, T. A., Ciais, P., Delbart, N., Friedl, M. A., Gobron, N., et al. (2010). Influence of spring and autumn phenological transitions on forest ecosystem productivity. Philos. Trans. R. Soc. B Biol. Sci. 365, 3227-3246. doi: 10.1098/rstb.2010.0102

Richardson, A. D., Hollinger, D. Y., Dail, D. B., Lee, J. T., Munger, J. W. 
and O'Keefe, J. (2009). Influence of spring phenology on seasonal and annual carbon balance in two contrasting New England forests. Tree Physiol. 29, 321-331. doi: 10.1093/treephys/tpn040

Robson, T. M., Sánchez-Gómez, D., Cano, F. J., and Aranda, I. (2012). Variation in functional leaf traits among beech provenances during a Spanish summer reflects the differences in their origin. Tree Genet. Genomes 8, 1111-1121. doi: 10.1007/s11295-012-0496-5

Rosas, T., Galiano, L., Ogaya, R., Peñuelas, J., and Martínez-Vilalta, J. (2013). Dynamics of nonstructural carbohydrates in three Mediterranean woody species under long-term experimental drought. Front. Plant Sci. 4:400. doi: 10.3389/ fpls.2013.00400

Rose, L., Leuschner, C., Köckemann, B., and Buschmann, H. (2009). Are marginal beech (Fagus sylvatica L.) provenances a source for drought tolerant ecotypes. Eur. J. For. Res. 128, 335-343. doi: 10.1007/s10342009-0268-4

Rossi, S., Deslauriers, A., Griçar, J., Seo, J.-W., Rathgeber, C. B., Anfodillo, T., et al. (2008). Critical temperatures for xylogenesis in conifers of cold climates. Glob. Ecol. Biogeogr. 17, 696-707. doi: 10.1111/j.14668238.2008.00417.x

Rossi, S., Morin, H., Deslauriers, A., and Plourde, P.-Y. (2011). Predicting xylem phenology in black spruce under climate warming. Glob. Change Biol. 17, 614-625. doi: 10.1111/j.1365-2486.2010.02191.x

Rouget, M., Richardson, D. M., Lavorel, S., Vayreda, J., Gracia, C., and Milton, S. J. (2001). Determinants of distribution of six Pinus species in Catalonia, Spain. J. Veg. Sci. 12, 491-502. doi: 10.2307/3237001

Ruiz-Benito, P., Lines, E. R., GoìmezAparicio, L., Zavala, M. A., and Coomes, D. A. (2013). Patterns and drivers of tree mortality in Iberian forests: climatic effects are modified by competition. PLOS ONE 8:e56843. doi: 10.1371/journal.pone. 0056843

Ruiz-Labourdette, D., Nogués-Bravo, D., Ollero, H. S., Schmitz, M. F., and Pineda, F. D. (2012). Forest composition in Mediterranean mountains is projected to shift along the entire elevational gradient under climate change. J. Biogeogr. 39, 162-176. doi: 10.1111/j.1365-2699.2011.02592.x

Sala, A., Woodruff, D. R., and Meinzer, F. C. (2012). Carbon dynamics in trees: feast or famine.
Tree Physiol. 32, 1-12. doi: 10.1093/treephys/tpr143

Salleo, S., Lo Gullo, M. A., Trifilo, P., and Nardini, A. (2004). New evidence for a role of vessel-associated cells and phloem in the rapid xylem refilling of cavitated stems of Laurus nobilis L. Plant Cell Environ. 27, 1065-1076. doi: 10.1111/j.13653040.2004.01211.x

Sánchez-Gómez, D., Zavala, M. A., Van Schalkwijk, D. B., Urbieta, I. R., and Valladares, F. (2008). Rank reversals in tree growth along tree size, competition and climatic gradients for four forest canopy dominant species in central Spain. Ann. For. Sci. 65, 605-613. doi: 10.1051/forest:2008040

Sánchez-Salguero, R., NavarroCerrillo, R. M., Camarero, J. J., and Fernández-Cancio, Á. (2012). Selective drought-induced decline of pine species in southeastern Spain. Clim. Change 113, 767-785. doi: 10.1007/s10584011-0372-6

Santos, L., Notivol, E., Zas, R., Chambel, M. R., Majada, J., and Climent, J. (2010). Variation of early reproductive allocation in multi-site genetic trials of Maritime pine and Aleppo pine. For. Syst. 19, 381-392.

Sanz-Pérez, V., Castro-Díez, P., and Valladares, F. (2009). Differential and interactive effects of temperature and photoperiod on budburst and carbon reserves in two co-occurring Mediterranean oaks. Plant Biol. 11, 142-151. doi: 10.1111/j.1438-8677.2008.00119.x

Sarris, D., Christodoulakis, D., and Körner, C. (2007). Recent decline in precipitation and tree growth in the eastern Mediterranean. Glob. Change Biol. 13, 1187-1200. doi: $\quad 10.1111 / j .1365-2486$. 2007.01348.x

Sharkey, T., and Bernacchi, C. (2012). "Photosynthetic responses to high temperature, " in Terrestrial Photosyntesis in a Changing Environment, eds J. Flexas, F. Loreto, and H. Medrano (New York, NY: Cambridge University Press), 290-298. doi: 10.1017/CBO9781 139051477.023

Sheffer, E. (2012). A review of the development of Mediterranean pine-oak ecosystems after land abandonment and afforestation: are they novel ecosystems. Ann. For. Sci. 69, 429-443. doi: 10.1007/s13595011-0181-0

Smith, N. G., and Dukes, J. S. (2013). Plant respiration and photosynthesis in global-scale models: incorporating acclimation to temperature and $\mathrm{CO} 2$. Glob. Change Biol. 19, 45-63. doi: 10.1111/j.1365-2486.2012.02797.x

Sperry, J. S., Meinzer, F. C., and McCulloh, K. A. (2008). Safety and efficiency conflicts in hydraulic architecture: scaling from tissues to trees. Plant Cell Environ. 31, 632-645. doi: 10.1111/j.1365-3040.2007.01765.x

Sperry, J. S., and Sullivan, J. E. M. (1992). Xylem embolism in response to freeze-thaw cycles and water stress in ring-porous, diffuse-porous, and conifer species. Plant Physiol. 100, 605-613. doi: 10.1104/pp.100.2.605

Stefanescu, C., Carnicer, J., and Penuelas, J. (2011). Determinants of species richness in generalist and specialist Mediterranean butterflies: the negative synergistic forces of climate and habitat change. Ecography 34, 353-363. doi: 10.1111/j.1600-0587.2010.06264.x

Tognetti, R., Longobucco, A., and Raschi, A. (1998). Vulnerability of xylem to embolism in relation to plant hydraulic resistance in Quercus pubescens and Quercus ilex co-occurring in a Mediterranean coppice stand in central Italy. New Phytol. 139, 347-448. doi: 10.1046/j.1469-8137. 1998.00207.x

Tyree, M. T., and Sperry, J. S. (1988). Do woody plants operate near the point of catastrophic xylem dysfunction caused by dynamic water stress? Answers from a model. Plant Physiol. 88, 574-580. doi 10.1104/pp.88.3.574

Tyree, M. T., and Zimmermann, N E. (1988). Xylem Structure and the Ascent of Sap. 2nd Edn. Berlin: Springer Berlin/Heidelberg.

Vayreda, J., Gracia, M. Martinez-Vilalta, J., and Retana, J. (2013). Patterns and drivers of regeneration of tree species in forests of peninsular Spain. J. Biogeogr. 40, 1252-1265. doi: 10.1111/jbi.12105

Vayreda, J., Martinez-Vilalta, J., Gracia, M., and Retana, J. (2012) Recent climate changes interact with stand structure and management to determine changes in tree carbon stocks in Spanish forests. Glob. Change Biol. 18, 1028-1041. doi: 10.1111/j.13652486.2011.02606. $\mathrm{x}$

Vilà-Cabrera, A., Martínez-Vilalta, J., Vayreda, J., and Retana, J. (2011). Structural and climatic determinants of demographic rates of Scots pine forests across the Iberian Peninsula. Ecol. Appl. 21, 1162-1172. doi: 10.1890/10-0647.1
Vitasse, Y., Bresson, C. C., Kremer, A., Michalet, R., and Delzon, R. (2010). Quantifying phenological plasticity to temperature in two temperate tree species. Funct. Ecol. 24, 1211-1218. doi: 10.1111/j.13652435.2010.01748.x

Vitasse, Y., Hoch, G., Randin, C. F., Lenz, A., Kollas, C., Scheepens, J. F., et al. (2013). Elevational adaptation and plasticity in seedling phenology of temperate deciduous tree species. Oecologia 171, 663-678. doi: 10.1007/s00442-012-2580-9

Vitasse, Y., Porté, A. J., Kremer A., Michalet, R., and Delzon, S. (2009a). Responses of canopy duration to temperature changes in four temperate tree species: relative contributions of spring and autumn leaf phenology. Oecologia 161, 187-198. doi: 10.1007/s00442-009-1363-4

Vitasse, Y., Delzon, S., Bresson, C. C., Michalet, R., and Kremer, A. (2009b). Altitudinal differentiation in growth and phenology among populations of temperate-zone tree species growing in a common garden. Can. J. For. Res. 39, 1259-1269. doi: 10.1139/X09-054

Voltas, J., Camarero, J. J., Carulla, D., Aguilera, M., Ortiz, A., and Ferrio, J. P. (2013). A retrospective, dual-isotope approach reveals individual predispositions to winterdrought induced tree dieback in the southernmost distribution limit of Scots pine. Plant Cell Environ. 36, 1435-1448. doi: 10.1111/pce.12072

Voltas, J., Chambel, M., Prada, M., and Ferrio, J. (2008). Climate-related variability in carbon and oxygen stable isotopes among populations of Aleppo pine grown in common garden tests. Trees 22, 759-769. doi: 10.1007/s00468-008-0236-5

Wang, J., Ives, N., and Lechowicz, M. J. (1992). The relation of foliar phenology to xylem embolism in trees. Funct. Ecol. 6, 469-475. doi: $10.2307 / 2389285$

Way, D. A., and Oren, R. (2010). Differential responses to changes in growth temperature between trees from different functional groups and biomes: a review and synthesis of data. Tree Physiol. 30, 669-688. doi: 10.1093/treephys/tpq015

Welp, L. R., Randerson, J. T., and Liu, H. P. (2007). The sensitivity of carbon fluxes to spring warming and summer drought depends on plant functional type in boreal forest ecosystems. Agric. For. Meteorol. 147, 172-185. doi: 10.1016/j.agrformet.2007.07.010

White, M. A., Running, S. W., and Thornton, P. E. (1999). The impact of growing-season length variability 
on carbon assimilation and evapotranspiration over 88 years in the eastern US deciduous forest. Int. J. Biometeorol. 42, 139-145. doi: 10.1007/s004840050097

Wright, I. J., Reich, P. B., Westoby, M., Ackerly, D. D., Baruch, Z., Bongers, F., et al. (2004). The worldwide leaf economics spectrum. Nature 428, 821-827. doi: 10.1038/nature02403

Wu, Z., Dijkstra, P., Koch, G. W., Peñuelas, J., and Hungate, B. A. (2011). Responses of terrestrial ecosystems to temperature and precipitation change: a meta-analysis of experimental manipulation. Glob. Change Biol. 17, 927-942. doi: 10.1111/j.13652486.2010.02302.x

$\mathrm{Yu}, \mathrm{H}$., Luedeling, E., and $\mathrm{Xu}, \mathrm{J}$. (2010). Winter and spring warming result in delayed spring phenology on the Tibetan Plateau.
Proc. Natl. Acad. Sci. U.S.A. 107, 22151-22156. doi: 10.1073/pnas. 1012490107

Zavala, M. A., Espelta, J. M., Caspersen, J., and Retana, J. (2011). Interspecific differences in sapling performance with respect to light and aridity gradients in Mediterranean pine-oak forests: implications for species coexistence. Can. J. For. Res. 41, 1432-1444. doi: 10.1139/x11-050

Zhang, S.-B., Slik, J. W. F., Zhang, J.-L., and Cao, K.-F. (2011). Spatial patterns of wood traits in China are controlled by phylogeny and the environment. Glob. Ecol. Biogeogr. 20, 241-250. doi: $\quad 10.1111 / \mathrm{j} .1466-8238.2010$. 00582.x

Zufferey, V., Cochard, H., Ameglio, T., Spring, J.-L., and Viret, $\mathrm{O}$. (2011). Diurnal cycles of embolism formation and repair in petioles of grapevine (Vitis vinifera cv. Chasselas). J. Exp. Bot. 62 , 3885-3894. doi: 10.1093/jxb/err081 Zweifel, R., Steppe, K., and Sterck, F. J. (2007). Stomatal regulation by microclimate and tree water relations: interpreting ecophysiological field data with a hydraulic plant model. J. Exp. Bot. 58, 2113-2131. doi: 10.1093/jxb/erm 050

Conflict of Interest Statement: The authors declare that the research was conducted in the absence of any commercial or financial relationships that could be construed as a potential conflict of interest.

Received: 25 June 2013; accepted: 26 September 2013; published online: 17 October 2013.
Citation: Carnicer J, Barbeta A, Sperlich D, Coll $M$ and Peñuelas $J$ (2013) Contrasting trait syndromes in angiosperms and conifers are associated with different responses of tree growth to temperature on a large scale. Front. Plant Sci. 4:409. doi: 10.3389/fpls.2013.00409 This article was submitted to Functional Plant Ecology, a section of the journal Frontiers in Plant Science.

Copyright (c) 2013 Carnicer, Barbeta, Sperlich, Coll and Peñuelas. This is an open-access article distributed under the terms of the Creative Commons Attribution License (CC BY). The use, distribution or reproduction in other forums is permitted, provided the original author(s) or licensor are credited and that the original publication in this journal is cited, in accordance with accepted academic practice. No use, distribution or reproduction is permitted which does not comply with these terms. 